\section{Federal Technology Alert}

A publication series designed to speed the adoption of energy: efficient and renewable technologies in the Federal sector

Prepared by the New Technology Demonstration Program

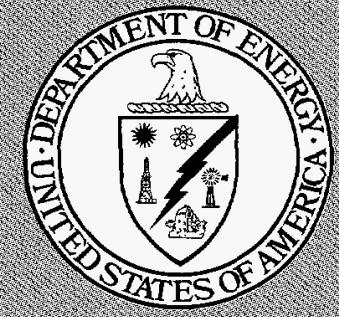

The U.S Deparment of Energy requests that no alterations be made without permission in any reprodiction of this docinent

DOE/EE-0173

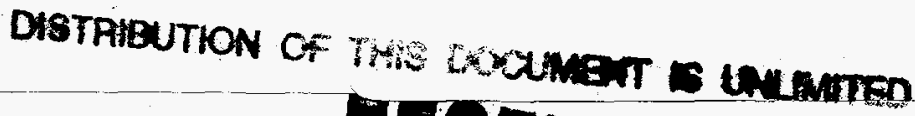
MEOEIVEO atp 20

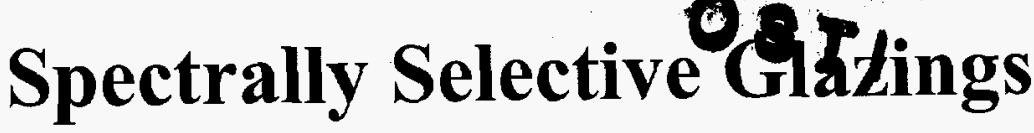

A well proven window technology to reduce energy costs while enhancing daylight and view

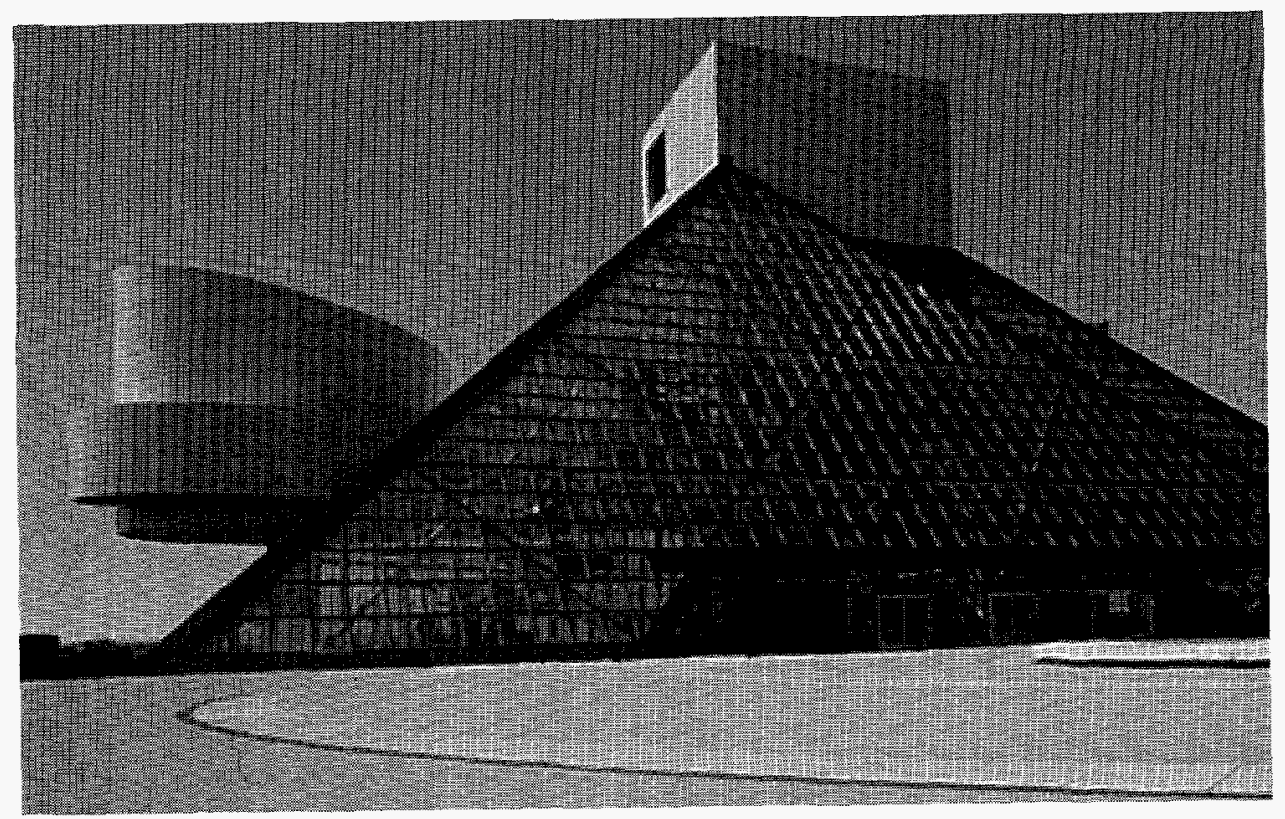

Spectrally selective glazing is window glass that permits some portions of the solar spectrum to enter a building while blocking others. This high-performance glazing admits as much daylight as possible while preventing transmission of as much solar heat as possible. By controlling solar heat gains in summer, preventing loss of interior heat in winter, and allowing occupants to reduce electric lighting use by making maximum use of daylight, spectrally selective glazing significantly reduces building energy consumption and peak demand. Because new spectrally selective glazings can have a virtually clear appearance, they admit more daylight and permit much brighter, more open views to the outside while still providing the solar control of the dark, reflective energy-efficient glass of the past.

Because of its solar heat transmission properties, spectrally selective glazing benefits both buildings in warm climates where solar heat gain can be a problem and buildings in colder climates where solar heat gains in summer and interior heat loss in winter are both of concern. In other words, these glazings are appropriate for residential and commercial buildings throughout the United States. The energy efficiency of spectrally selective glazing means that architects who use it can incorporate more glazing area than was possible in the past within the limitations of codes and standards specifying minimum energy performance. When spectrally selective glazing is 
used, the capacity of the building's cooling system can also be downsized because of reduced peak loads.

Spectrally selective glazings screen out or reflect heat-generating ultraviolet and infrared radiation arriving at a building's exterior surface while permitting most visible light to enter. Spectral selectivity is achieved by a microscopically thin, low-emissivity (low-E) coating on the glass or on a film applied to the glass. There are also carefully engineered types of blue- and green-tinted glass that can perform as well in a double-pane unit as some glass with a low-E coating. Conventional blue- and green-tinted glass can offer some of the same spectral properties as these special absorbers because impurities in tinted glass absorb portions of the solar spectrum. Absorption is less efficient than reflection, however, because heat absorbed by tinted glass continues to radiate to the building's interior.

This Federal Technology Alert (FTA) of the Federal Energy Management Program (FEMP) is one of a series of publications on new, energy-efficient technologies that have potential for widespread use in Federal buildings. The body of this report describes the types of spectrally selective glazings, the situations in which they are most likely to be cost-effective, and considerations for selecting and installing them. Several case studies are included.

\section{Application}

Spectrally selective glazings can be used in windows, skylights, glass doors, and atria of commercial and residential buildings.

This technology is most costeffective for residential and nonresidential facilities that have large cooling loads, high utility rates, poorly performing existing glazing (such as single-pane clear glass or dark tinted glass), or are located in the southern United States. In the northern United States, spectrally selective low-E windows can also be cost-effective for buildings with both heating and cooling requirements.

In general, the technology pays back in 3 to 10 years for U.S. commercial buildings where it replaces clear single-pane or tinted doublepane glass and for most commercial buildings in the southern United States where it replaces conventional hightransmission, low-E, double-pane windows. Spectrally selective glazing is applicable in both new and retrofit construction.

\section{Technology Selection}

The FTA series targets new energyefficient technologies that appear to have significant untapped potential in Federal buildings. Many of the alerts are about new technologies identified through advertisements in the Commerce Business Daily and trade journals and through direct correspondence in response to an open solicitation for technology ideas. Spectrally selective glazing is an energy efficiency technology with known energy, cost, and environmental benefits for which there is substantial, untapped potential in Federal buildings.

\section{Case Studies}

This report gives case study examples by glazing type-selective low-E glazings, selective tinted glazings, and selective window filmsfor residential and nonresidential facilities and new and retrofit construction. Detailed energy simulations are seldom conducted to justify the selection of window systems and monitored data cannot be obtained directly. Therefore, multiple case studies are offered to show how several users approached the selection and justified the cost of spectrally selective windows.

\section{Implementation Barriers}

There are no technological barriers to the use of spectrally selective windows. Cost-effectiveness varies by geographical area, type of use, and utility rates, but suitable applications exist in all types of buildings and parts of the country.

If decisions about window design are made based only on cost-effectiveness and greatest energy efficiency, physiological and psychological concerns of building occupants may be overlooked. The most cost-effective and energy-efficient window may be a dark, reflective window that offers building occupants little or no daylight and view. Spectrally selective glazing's incremental additional cost may be justified if its clear appearance, enhanced view, and improved comfort are taken into account.

In retrofit applications, spectrally selective glazing is often appreciated because it reduces complaints from occupants who have lived with the discomfort of poorly performing glazing, and it reduces high utility bills, particularly during peak cooling periods. Building managers may have faced high vacancy rates in spaces where non-spectrally selective glazing causes discomfort. (Retrofit examples for the Tucson and Oakland Federal Buildings later in this report address the improvement in occupants' comfort that can result from installation of spectrally selective glazing.) 


\section{DISCLAIMER}

This report was prepared as an account of work sponsored by an agency of the United States Government. Neither the United States Government nor any agency thereof, nor any of their employees, makes any warranty, express or implied, or assumes any legal liability or responsibility for the accuracy, completeness, or usefulness of any information, apparatus, product, or process disclosed, or represents that its use would not infringe privately owned rights. Reference herein to any specific commercial product, process, or service by trade name, trademark, manufacturer, or otherwise does not necessarily constitute or imply its endorsement, recommendation, or favoring by the United States Government or any agency thereof. The views and opinions of authors expressed herein do not necessarily state or reflect those of the United States Government or any agency thereof. 


\section{DISCLAIMER}

Portions of this document may be illegible in electronic image products. Images are produced from the best available original document. 


\section{Federal Technology Alert}

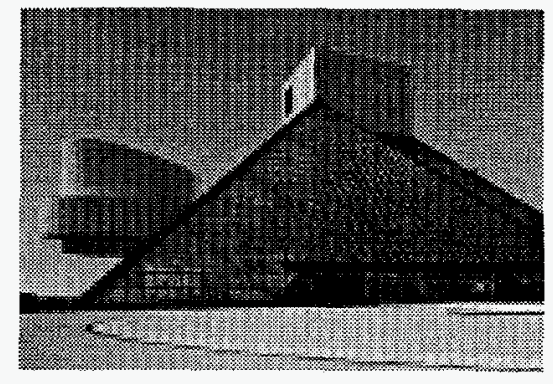

Compare the clear appearance of the spectrally selective glass used in the Rock and Roll Hall of Fame in Cleveland, Ohio (above) to appearance of the dark reflective glass used in the Piper Jaffray tower in Minneapolis, Minnesota (below). Selective coating on clear doublepane glass (above): visible transmittance $(T v)=0.70$, solar heat gain coefficient $(\mathrm{SHGC})=\mathbf{0 . 3 7}$; Double-pane, titanium coating on blue reflective glass (below): $T v=0.19$, SHGC $=0.21$.

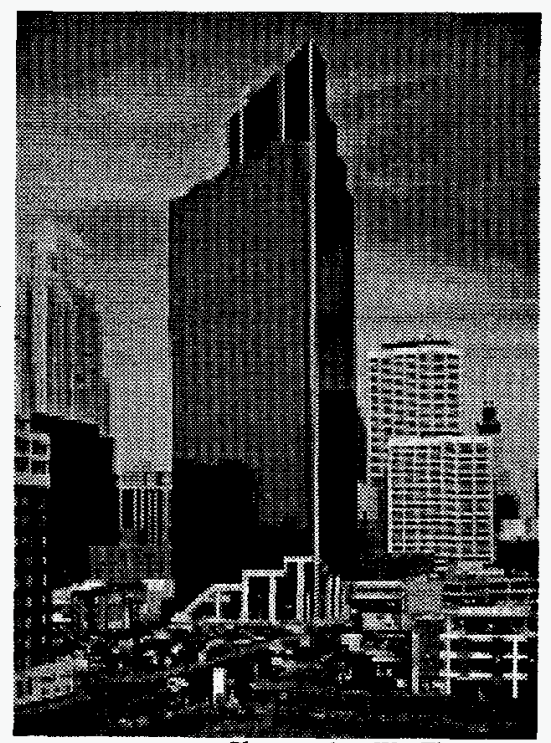

Photographer: Wes Thompson

\title{
Spectrally Selective Glazings
}

\author{
A well proven window technology to reduce energy costs while enhancing \\ daylight and view
}

\section{Abstract}

Spectrally selective glazing is window glass that permits some portions of the solar spectrum to enter a building while blocking others. This high-performance glazing admits as much daylight as possible while preventing transmission of as much solar heat as possible. By controlling solar heat gains in summer, preventing loss of interior heat in winter, and allowing occupants to reduce electric lighting use by making maximum use of daylight, spectrally selective glazing significantly reduces building energy consumption and peak demand. Because new spectrally selective glazings can have a virtually clear appearance, they admit more daylight and permit much brighter, more open views to the outside while still providing the solar control of the dark, reflective energy-efficient glass of the past, as shown in the figures on the left.

Because of its solar heat transmission properties, spectrally selective glazing benefits both buildings in warm climates where solar heat gain can be a problem and buildings in colder climates where solar heat gains in summer and interior heat loss in winter are both of concern. In other words, these glazings are appropriate for residential and commercial buildings throughout the United States. The energy efficiency of spectrally selective glazing means that architects who use it can incorporate more glazing area than was possible in the past within the limitations of codes and standards specifying minimum energy performance. When spectrally selective glazing is used, the capacity of the building's cooling system can also be downsized because of reduced peak loads.

Spectrally selective glazings screen out or reflect heat-generating ultraviolet and infrared radiation arriving at a building's exterior surface while permitting most visible light to enter. Spectral selectivity is achieved by a microscopically thin, low-emissivity (low-E) coating on the glass or on a film applied to the glass. There are also carefully engineered types of blue- and green-tinted glass that can perform as well in a double-pane unit as some glass with a low-E coating. Conventional blue- and green-tinted glass can offer some of the same spectral properties as these special absorbers because impurities in tinted glass absorb portions of the solar spectrum. Absorption is less efficient than reflection, however, because heat absorbed by tinted glass continues to radiate to the building's interior.

This technology is most costeffective for residential and nonresidential facilities that have high cooling loads, high utility rates, poorly performing existing glazing (such as single-pane clear glass or dark tinted glass), or are located in the southern United States. In the northern United States, spectrally 
selective low-E windows can also be cost-effective for buildings with both heating and cooling requirements.

In general, the technology pays back in 3 to 10 years for U.S. commercial buildings where it replaces clear single-pane or tinted doublepane glass and for most commercial buildings in the southern United States where it replaces low-E, double-pane windows. Spectrally selective glazing is applicable in both new and retrofit construction.

This Federal Technology Alert provides detailed information and procedures for Federal energy managers to consider spectrally selective glazings. The principle of spectrally selective glazings is explained. Benefits related to energy efficiency and other architectural criteria are delineated. Guidelines are provided for appropriate application of spectrally selective glazing, and step-by-step instructions are given for estimating energy savings. Case studies are also presented to illustrate actual costs and energy savings. Current manufacturers, technology users, and references for further reading are included for users who have questions not fully addressed here. 


\section{Contents}

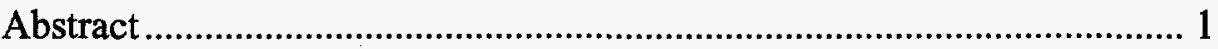

About the Technology ............................................................................. 5

Application Domain

Energy-Saving Mechanism

SHGC and Tv

Energy Benefits

Other Benefits

Variations

Other Architectural Criteria

Installation

Federal Sector Potential

Technology Screening Process

Estimated Savings and Market Potential

Laboratory Perspective

Application 19

Application Screening

Where to Apply

What to Avoid

Equipment Integration

Maintenance Impact

Warranties

Codes and Standards

Costs

Utility Incentives and Support

Technology Performance

Case Studies.

New U.S. Courthouse, Tucson, Arizona

Case Studies using Spectrally Selective Suspended Film

New U.S. Courthouse, Sacramento, California

New U.S. Courthouse, Tampa, Florida

Retrofit of Federal Building, Tucson, Arizona-Detailed Case Study

Window Films, Oakland Federal Building

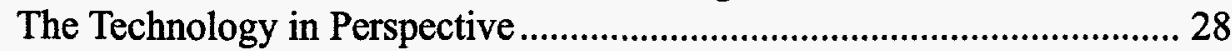

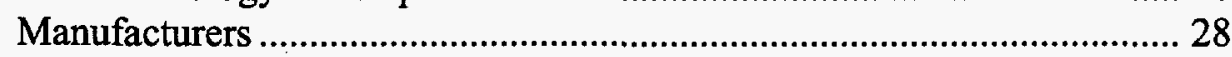

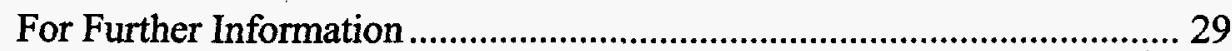

Organizations

Software

Literature

Books

References

Appendixes

Appendix A Properties of Spectrally Selective Glazings for Nonresidential and Residential Applications 
Appendix B Energy Performance Analysis.

Appendix C Energy, Peak Demand, and Cost Data from the Simulations

Appendix D Federal Life-Cycle Cost Analysis for the Tucson Federal Building, Tucson, Arizona ....................... 40

Appendix E Federal Life-Cycle Costing Procedures and the BLCC Software 


\section{About the Technology}

Buildings account for more than one-third of all U.S. energy consumption, 30 to $40 \%$ of which is directly attributable to cooling and lighting electricity use and heating by natural gas, coal, electricity, or oil. Energy policy has emphasized the development of new "secure" energy supply options such as offshore oil, but advanced building technologies such as spectrally selective glazings that effectively reduce energy consumption can also be viewed as a "supply" option.

Spectrally selective glazing is a glazing system that permits some portions of the solar spectrum to enter a building while blocking others. This high-performance glazing admits as much daylight as possible while preventing transmission of as much solar heat as possible. By controlling solar heat gains in summer, preventing loss of interior heat in winter, and allowing occupants to reduce electric lighting use by making maximum use of daylight, spectrally selective glazing significantly reduces building energy consumption and peak demand. Because new spectrally selective glazings can have a virtually clear appearance, they admit more daylight and permit much brighter, more open views to the outside while still providing the solar control of the dark, reflective energyefficient glass of the past (Figure 1).

Because of its solar heat transmission properties, spectrally selective glazing benefits both buildings in warm climates where solar heat gain can be a problem and buildings in colder climates where solar heat gains in summer and interior heat loss in winter are both of concern. In other words, these glazings are appropriate for residential and commercial buildings throughout the United States. The energy efficiency of spectrally selective glazing means that architects who use it can incorporate more glazing area than was possible in the past within the limitations of codes and standards specifying minimum energy performance. When spectrally selective glazing is used, the capacity of

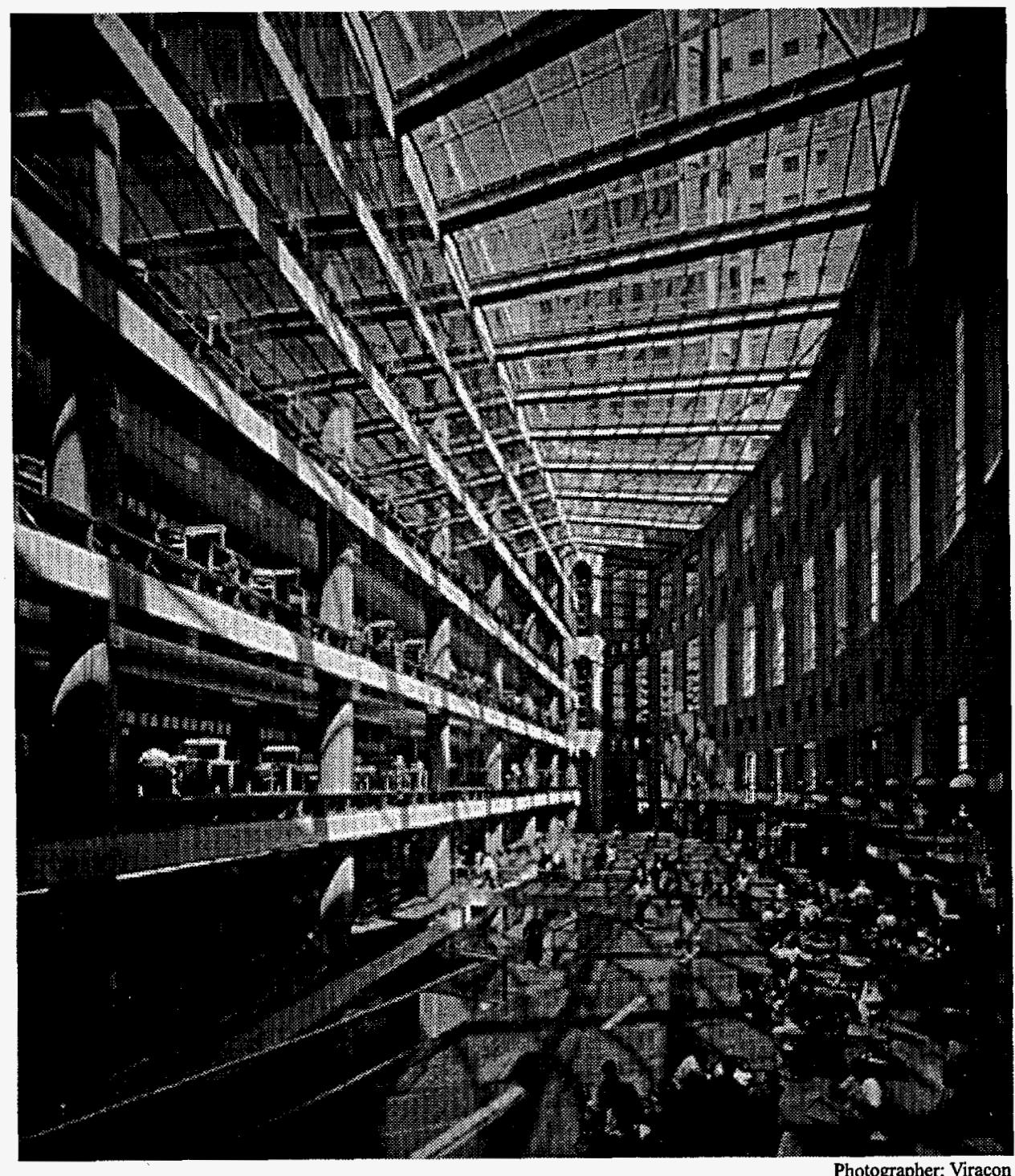

Figure 1. New Spectrally Selective Glazings at the Vancouver Library Atrium (The atrium offers viewers a clear connection to the outdoors without the uncomfortable heat gains associated with clear glass. The glazing is double-pane selective coating on clear glass: $\mathrm{T} v=0.70, \mathrm{SHGC}=0.37$.) the building's cooling system can also be downsized because of reduced peak loads.

Spectrally selective glazings screen out or reflect heat-generating ultraviolet and infrared radiation arriving at a building's exterior surface while permitting most visible light to enter. Spectral selectivity is achieved by a microscopically thin, low-emissivity 
Whidow. or OT Wuls?

Comsider the tollowing arginient Ar

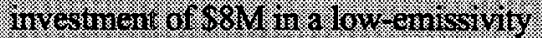

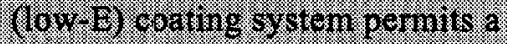
manufacturer to prodice $1.86 \mathrm{Mm}^{2}$

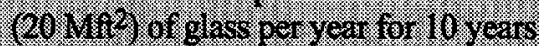
and aceminlate energy su ving ding

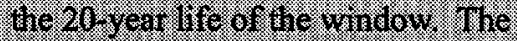

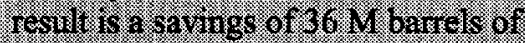
o1lequivalen:

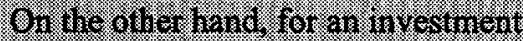

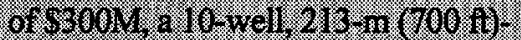

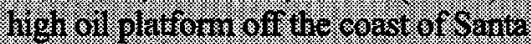

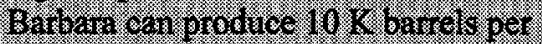

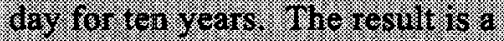

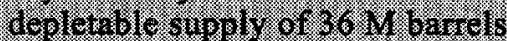

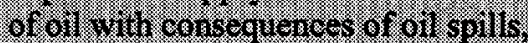

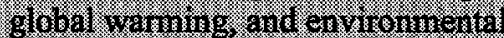
pollution.

(low-E) coating on the glass or on a film applied to the glass. There are also carefully engineered types of blue- and green-tinted glass that can perform as well in a double-pane unit as some glass with a low-E coating. Conventional blue- and green-tinted glass can offer some of the same spectral properties as these special absorbers because impurities in tinted glass absorb portions of the solar spectrum. Absorption is less efficient than reflection, however, because heat absorbed by tinted glass continues to radiate to the building's interior.

Spectrally selective glazings have been available since the 1980 s and have been used extensively in private and Federal facilities. The technology is proven, reliable, and applicable in a wide variety of building types. Designers' lack of knowledge about spectrally selective glazings has been the principle barrier to their full market adoption.

\section{Application Domain}

Spectrally selective glazings can be used in windows, skylights, glass doors, and atria in all types of commercial and residential buildings. The majority of window manufacturers offer spectrally selective glazings as standard products, so these glazings can be easily obtained through local distributors and installed using conventional glazing practices. The raw glazing itself is produced by glazing manufacturers, listed in the Manufacturers Section, then sent to local fabricators and distributors across the United States for assembly into window units.

This technology is likely to be cost-effective for facilities that provide space conditioning (heating and cooling), use electric lighting, and are subject to solar radiation. Because the cost of electricity for cooling and lighting tends to be more than the cost of gas, oil, or coal for heating, buildings with large cooling and lighting requirements are most likely to benefit from spectrally selective glazing. Some selective glazings also reduce radiant and conductive heat gains and losses (even in the winter) and so are also beneficial in buildings with both summer cooling and winter heating requirements.

\section{Energy-Saving Mechanism}

The solar spectrum includes ultraviolet, visible, and infrared radiation. Spectrally selective glazings absorb or reflect heat-generating infrared solar radiation but transmit daylight or visible solar radiation (Figure 2). Because visible solar radiation also contains heat, selective glazings can be designed to reflect some of this radiation as well. This FTA defines spectrally selective glazings as those that sharply cut off or reduce solar transmission beyond the visible range, with a total solar transmission of no less than $\sim 0.40$ in the visible range. Of the various glazings shown in Figure 3, only the spectrally selective glazing demonstrates a sharp cutoff of transmission beyond the visible range.

Spectral selectivity is most effectively achieved by using microscopically thin, silver-based, multilayer, low-E coatings on glass or film. These coatings reflect rather than absorb incident solar radiation; less absorbed energy means less heat is transferred into the building. Selective coatings also tend to have lower emissivity and thus radiate less heat into or out of a space than conventional low-E coatings do. The coating is applied to the glass after manufacturing using a sputtering process; the resulting soft coating requires protection in an insulating glass unit (IG) or laminated ${ }^{(a)}$ configuration. Coatings can also be deposited on a thin polymer film which can then be suspended

(a) Laminated glass does not inherently have spectrally selective properties. It relies on coated glass, tinted glass, or a coated film interlayer to achieve these properties. Laminated glass is a manufactured assembly of at least one sheet of glass bonded to at least one other sheet of glass or plastic glazing sheet material with an organic interlayer. The interlayer, usually a clear or tinted polyvinyl butyl (PVB) plastic, is specifically developed for bonding glass to glass or plastic. The thickness of the assembly typically is the same as standard monolithic glass sizes. When broken, glass fragments are intended to adhere to the interlayer. Laminated glass is now required to meet impact-resistant standards in Federal Courthouses. 


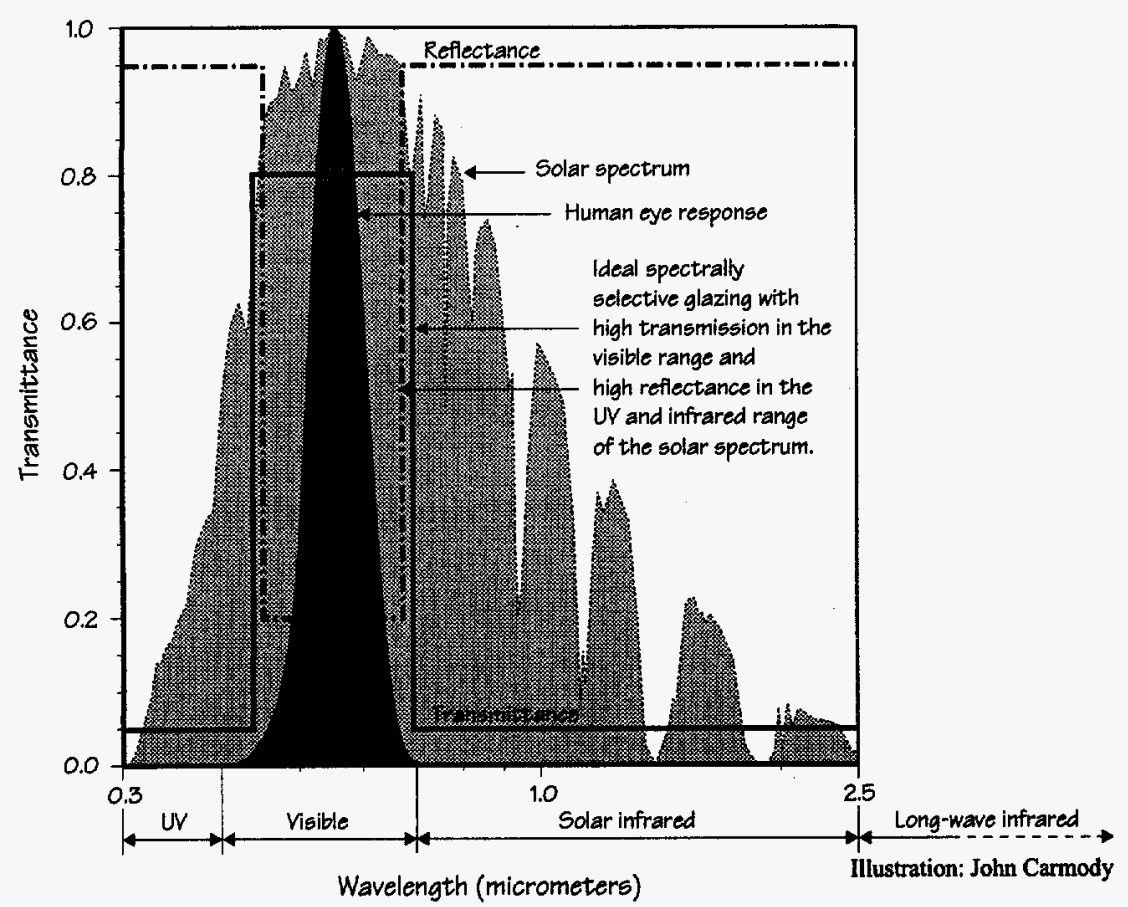

Figure 2. Solar Spectral Properties of an Ideal Spectrally Selective Glazing (The response curve represents the eye's response to light.)

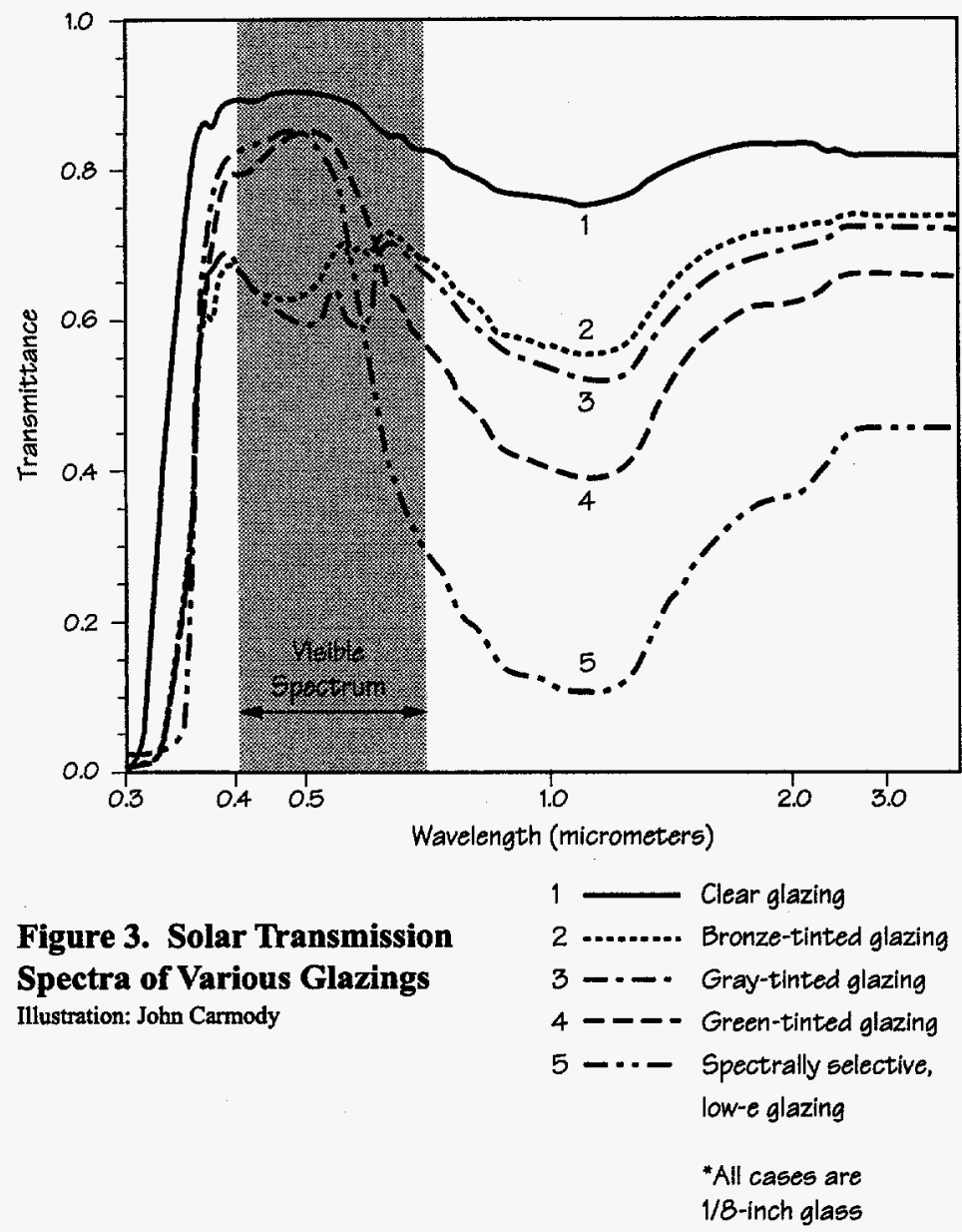

or laminated between two panes of glass or applied as a window film. The first spectrally selective coatings on glass were commercially available in the early 1980 s with individual manufacturers holding specific U.S. patents for their own processes.

Conventional green- or blue-tinted glazings can have a spectral response similar to spectrally selective glazings. Chemicals in this glass absorb portions of the solar spectrum, which is less efficient than reflecting heat because some of the absorbed radiation will continue to reradiate to the interior. So a tint by itself can only achieve a modest level of reduction in solar heat transmission. Spectrally selective products are limited to the blue-green family; other colors (e.g., bronze, gray) are not currently considered selective although manufacturers continue to develop new products.

Blue-, green-, and aqua-tinted glass has been engineered during the past 10 to 15 years to increase spectral selectivity with a clearer appearance. These spectrally selective tints can provide increased solar control when combined with a selective low-E coating. For best performance, tinted glazings should be used in an insulating glass unit with the tinted pane on the exterior to minimize reradiation of absorbed heat to the interior.

Low-E pyrolytic (hard) coatings on glass, applied directly to a hot glass surface during manufacture, are not selective because they tend to transmit solar radiation evenly throughout the solar spectrum. They can be combined with selective tinted glass to achieve better performance. 


\section{SHGC and Tv}

The most important performance variables for spectrally selective glazings are the solar heat gain coefficient (SHGC) and visible transmittance (Tv) of the glazing. The solar heat gain coefficient, a measure of total solar heat gain including both directly transmitted solar radiation and the inward flowing heat resulting from absorption by the glazing, has a direct effect on a building's cooling energy consumption, peak demand, and cooling system capacity.

Visible light transmittance is a measure of the percentage ( 0 to $100 \%$ ) of visible light transmitted by the glazing. The higher the $\mathrm{Tv}$, the closer interior daylight levels and view are to those provided by traditional clear glass, and the less tinted or mirrored effect is visible. Where manual or automatic lighting controls are used, transmission of daylight can substantially reduce electric lighting requirements and cooling loads associated with heat generated by the electric lighting system.

Two pieces of glass could have the same SHGC but appear very different —one glass might totally block all visible light (and appear black) while another might look completely transparent. Spectrally selective glazings have a high Tv and low SHGC. The ratio of these parameters, or the light-to-solar-gain ratio $(\mathrm{LSG}=\mathrm{Tv} / \mathrm{SHGC})$, is typically between 1.25-2.0. Higher LSG products are under development. Often, because selective coatings also have low emissivity, the conductance or "U-factor" is also low, reducing conductive heat gains through the window.

At present, a wide range of spectrally selective products can meet any type of window application throughout the United States. Figure 4 shows the SHGC and Tv of commercially available, spectrally selective, dualpane products for the nonresidential window market (see Appendix A for data on other product lines). Optimal products have low SHGC and high $\mathrm{Tv}$, which corresponds to the lower right corner of the plot. However, any daylight also carries heat, so it is impossible to have a Tv greater than zero and a SHGC equal to zero. This results in a "forbidden zone" in the lower right corner of the graph, which represents performance that is physically impossible to achieve. The "color zone" defines a region in which it is impossible to create a coating without color. Manufacturers continue to develop improved selective coatings, tints, and films.

\section{Energy Benefits}

The use of spectrally selective glazing will generally result in the following energy performance improvements over conventional glazing:

- Cooling energy from solar gains will decrease because of spectrally selective glazing's lower solar heat gain coefficient.

- Lighting energy will decrease (if manual or automatic lighting controls are available) because of spectrally selective glazing's higher visible transmittance.

- Required heating energy may decrease if spectrally selective glazings with lower thermal conductance and emissivity are used.

- Summer peak demand from cooling and lighting will decrease because

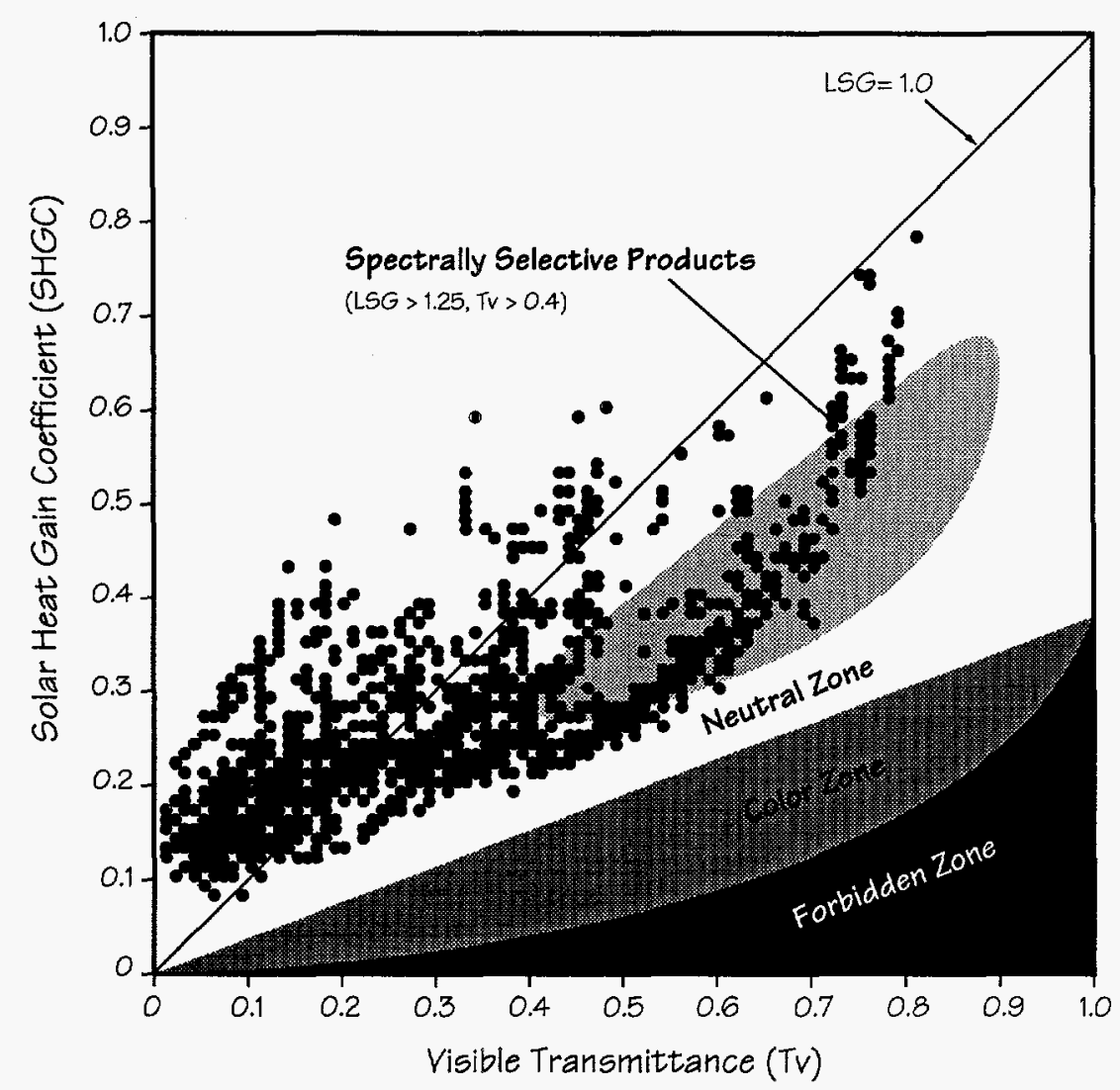

Figure 4. Center-of-Glass Properties of Commercially Available, Dual-pane, Spectrally Selective Glazings, Coatings, and Films for Commercial Applications 
spectrally selective glazings will produce a reduction in solar heat gains, electric lighting requirements, and electric lighting heat gains.

- Because peak demand is used to size cooling equipment in commercial buildings, a downsizing of mechanical system capacity is possible when spectrally selective glazings are used, allowing a reduction in first cost and higher system part-load efficiency.

\section{Other Benefits}

Designers and owners often select glazing products for aesthetic or nonenergy reasons. Spectrally selective glazings offer building occupants a number of direct aesthetic and comfort advantages:

- Because spectrally selective glazings reflect solar heat gains, the temperature of the interior glazing surface is often significantly cooler than that of the interior surface of absorptive tinted glazings, which absorb solar radiation that reradiates as heat to the interior. This is particularly true for monolithic (single-pane) glass with a heatabsorbing window film applied to the interior. Occupants sitting near this glass surface may be uncomfortable because of the difference between the hot window surface and the cooler interior (see Case Study: Retrofit of the Tucson Federal Building). Air conditioning can alleviate this problem to some degree (analogous to sitting in an air-conditioned room next to an oven). Building energy managers may be called in to "fix" the mechanical system in this situation even though the problem is in the control of radiant heat gains.
- Spectrally selective glazing is more transparent than tinted glazing, enabling occupants to have an unimpeded view and a sense of connection to the outdoors, as well as visual relief from tasks at hand. In contrast, low-transmission glazing can often alter the brightness and color of outdoor views, contributing to a lifeless interior space; occupants may feel cut off from time, weather, and the seasons.

- Spectrally selective glazings offer better night views than reflective and dark tinted glazings. Occupants can only see out of a reflective window at night if they turn out all interior lights; otherwise, the interior glass has a mirrored appearance. If light levels outdoors are low, reflective or heavily tinted glass will also reduce an occupant's ability to see what's going on outside.

- From the exterior, the appearance of spectrally selective glazing is clear, not mirrored or heavily tinted, even though it yields the same or better solar heat gain rejection capabilities as heavily tinted glass. Some zoning regulations in cities no longer permit the use of highly reflective glass (used extensively in the 1970s and early 1980 s throughout the United States) because it imposes its solar load on adjacent buildings, surrounding plazas, vegetation, and pedestrians, and can be a source of reflected glare.

- Where building energy codes place restrictions on a building's energy use, tradeoffs between glass type and glazing area must often be made. With spectrally selective glazings, window area can be increased; e.g., for a building with clear, single-pane glass, the glazing area may be restricted to $15-20 \%$ of the exterior wall area, but with spectrally selective, insulating glass, a $50 \%$ glazing area may be allowed.

- For some glass products, low ultraviolet transmission can reduce fading of interior furnishings and fabrics (depending on the intensity and duration of solar radiation).

- One difficult issue raised by spectrally selective glazings is the likelihood of glare when visible transmittance is high. A typical office space receives daylight from only one side; the difference in brightness between the window and the darker interior can result in visual discomfort because of contrast glare. If glare is a critical issue year round, glazing with a lower Tv can be used. Other solutions include using light shelves, light-colored interior finishes, splayed window jambs, or brightening the back of the room with a skylight or other light sources. Direct sunlight glare is best avoided by window orientation, placement, sizing, and proper use of interior and exterior shading devices. For practical details, see the Illuminating Engineering Society's daylighting guide (RP-5-79) [(212) 248-5000 x112], or Tips for Daylighting with Windows at http://eetd.lbl.gov/btp/pub/ designguide.

\section{Variations}

A window is typically composed of one or more panes separated by metal spacers, gas fill (air, argon, or krypton) if more than one pane, one 
or two structural seals, and a frame (Figure 5). Advanced window systems often achieve high performance simply through the optimal configuration (position and type) of these various components (Figure 6).

Each component can be designed for energy efficiency. Spectrally selective coated glass, tinted and laminated glass, suspended films, and window films are the choices for "panes." Table 1 presents a comprehensive list of spectrally selective coatings, uncoated glass, and laminated glass interlayers. The window frame can be "thermally broken" (i.e., there is no continuous metal contact between outdoor and indoor window surfaces) or made out of wood or vinyl to reduce conductive heat transfer and resulting condensation problems. The choice of gas fill (i.e., air versus argon or krypton) between the panes can improve the insulating value of the window unit by reducing conductive heat transfer. For retrofit applications (historic structures, replacement glass, or storm windows), the window can be composed of the same components described above.

Manufacturers of window products typically sell "product lines" in which the choice of components is predetermined. For some commercial applications, however, one may wish to specify each component to meet design requirements. For example, to meet impact resistance requirements with an energy-efficient insulating glass (IG) unit, the interior pane may consist of a laminated clear glass configuration or the exterior pane may consist of a laminated spectrally selective combination, i.e.,

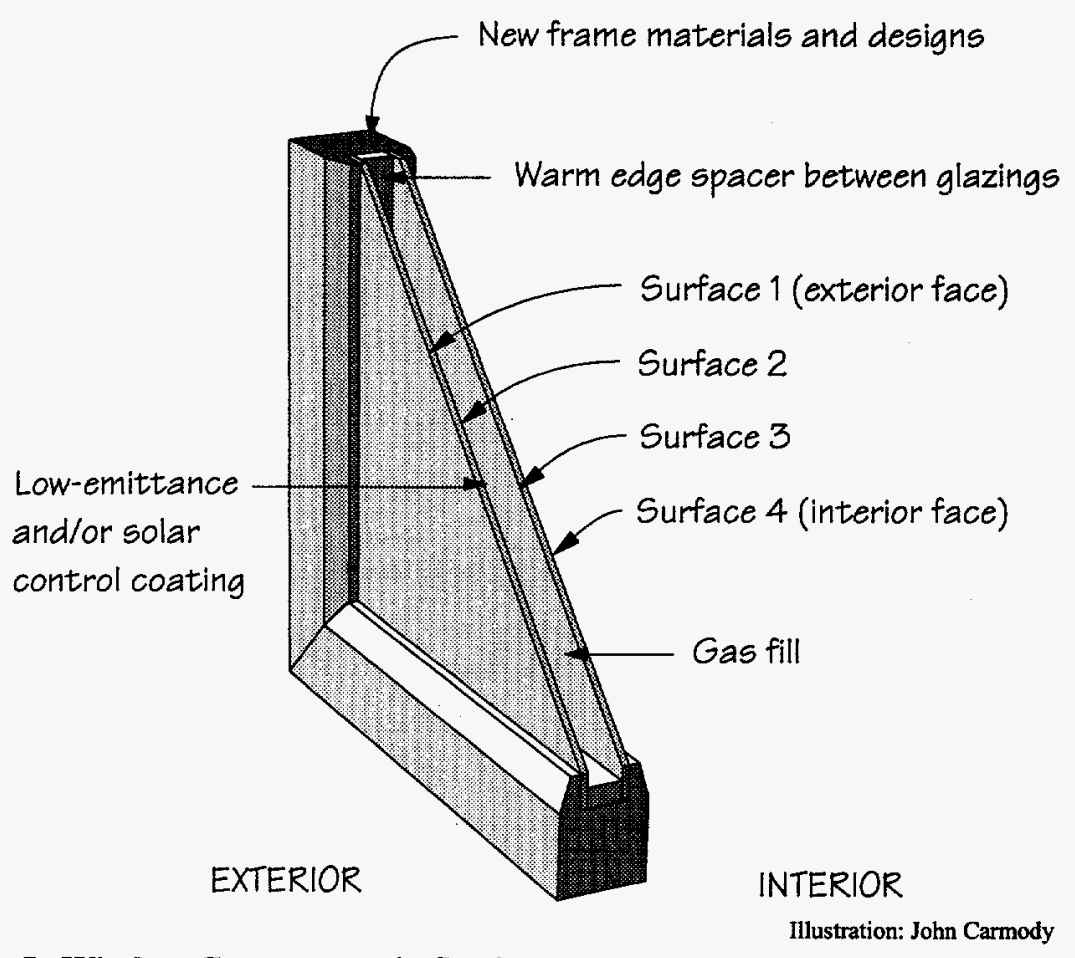

Figure 5. Window Components in Section

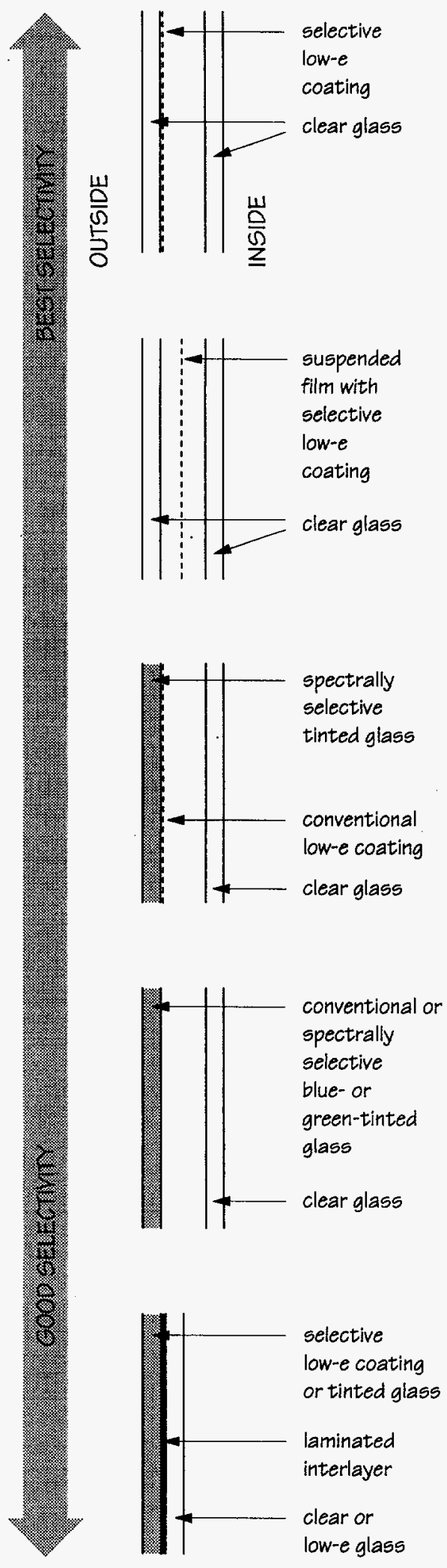

Figure 6. Spectrally Selective Window Assemblies 
Table 1. Commercially Available, Spectrally Selective Products, by Manufacturer

\begin{tabular}{|c|c|c|}
\hline Manufictarer: & 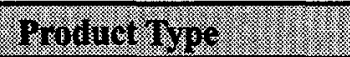 & Product: : \\
\hline AFG Industries & $\begin{array}{l}\text { Glass } \\
\text { Coatings }^{3}\end{array}$ & $\begin{array}{l}\text { Green } \\
\text { Blue-green } \\
\text { Azurlite } \AA^{2} \\
\text { Evergreen } \AA^{2} \\
\text { Silver }(\text { ES140, ES152, ESB1, and ESN1 })^{4}\end{array}$ \\
\hline Cardinal IG & Coatings & $\begin{array}{l}\text { LoE-178 } \\
\text { LoE }^{2}-171\end{array}$ \\
\hline Dupont Polymer Products & Laminate Interlayer & None. Interlayer can be used to laminate selective glass. ${ }^{6}$ \\
\hline Ford & Glass & Sunglas Green \\
\hline Guardian & $\begin{array}{l}\text { Glass } \\
\text { Coatings }\end{array}$ & $\begin{array}{l}\text { Green } \\
\text { Performance Plus } \\
\text { Performance Plus II }\end{array}$ \\
\hline Interpane & Unknown ${ }^{5}$ & \\
\hline Libby-Owens-Ford & Glass & $\begin{array}{l}\text { Blu-Green } \\
\text { Evergreen }(8)\end{array}$ \\
\hline Monsanto & Laminate Interlayer & Solarflex ${ }^{6}$ \\
\hline MSE Specialty Films & Unknown $^{5}$ & \\
\hline PPG & $\begin{array}{l}\text { Glass } \\
\text { Coatings }\end{array}$ & $\begin{array}{l}\text { Solex } \\
\text { Solargreen } \\
\text { Azurlite }( \\
\text { Sungate } 100 \\
\text { Sungate } 1000 \\
\end{array}$ \\
\hline Southwall Technologies & $\begin{array}{l}\text { Laminated Glass } \\
\text { Window Films } \\
\text { Suspended Heatmirror } \\
\text { Films in an IG Unit }\end{array}$ & $\begin{array}{l}\text { California Series XIR with: } \\
\text { Azurlite } \mathbb{B}^{2} \\
\text { Evergreen } \mathbb{B}^{2} \\
\text { Green } \\
\text { Solis Clear } \\
\text { HM44, HM55, HM66, HM77, HM88, } \\
\text { HMSC75 (Solar Control-75), HMTC88 (Twin-coated-88) }\end{array}$ \\
\hline 3M Corporation & Window Films & LE50AMARL \\
\hline Viracon & $\begin{array}{l}\text { Glass } \\
\text { Coatings }\end{array}$ & $\begin{array}{l}\text { Green } \\
\text { Blue-Green } \\
\text { Azurlite } \otimes^{2} \\
\text { Evergreen } \mathbb{B}^{2} \\
\text { Solarscreen } 2000 \\
\text { Solarscreen VH Series: VE1-85, VE1-55, VE1-52, VE1-40 }\end{array}$ \\
\hline
\end{tabular}

Notes:

1. We list spectrally selective products of known original equipment manufacturers. You can also check the Thomas Register of American Manufacturers or the Sweet's Catalog file. Spectrally selective products were determined by the following criteria: 1) exhibit sharp Tsol cut-off after $1.0 \mathrm{~nm}, 2)$ high Tsol $(>0.40)$ in the visible range, 3) solar spectral properties determined either for coating on 6-mm clear glass, single 6-mm layer of tinted glass, film on \#2 surface of 6-mm clear glass, or film suspended between two layers of 6-mm clear glass using spectral data provided by manufacturers and given in NFRC Spectral Data Library No. 5 (January 1998).

2. Azurlite is a registered trademark name and product of PPG. Evergreen is a registered trademark name and product of LOF.

3. Coatings can be used independently from the selective glass products in this table. For example, the AFG silver coating on clear glass will yield spectral selectivity.

4. The given product name refers to that noted in NFRC Spectral Data Library No. 5, provided by the manufacturer to NFRC. No analogous product with the same name was clearly listed in the manufacturer's catalog.

5. No spectral data available for this manufacturer so could not determine if selective products were offered.

6. Interlayer can be used to laminate two glass layers to form a single pane of laminated glass. 
clear glass, safety film, then low-E, spectrally selective glass. The manufacturer can often assist the customer in determining the final window properties of unique assemblies using a simulation program called WINDOW 4.

In the residential sector, glazings and configuration choices are more limited than in the commercial sector. For new residential applications, IG units offer the best performance and can look comparable to conventional clear glass. Residential window manufacturers sometimes do not give Tv and SGHC data on product lines. However, a uniform national energy performance rating and labeling system developed by the National Fenestration Rating Council (NFRC) enables builders and consumers to directly compare commercial and residential fenestration products, as can now be done with labels developed for appliances (e.g., refrigerators, dryers). Look for the NFRC label when purchasing windows for residential applications.

\section{Other Architectural Criteria}

Spectrally selective glazing products can be configured or designed to meet particular architectural criteria. The glass can be tempered or heatstrengthened for safety and structural stability. Products can meet shatter, bullet, and shock resistance and hurricane criteria and provide electromagnetic interference (EMI) shielding of sensitive computer information.

Spectrally selective glass products can also be curved for bay windows or skylights. More complex shapes may be restricted to single-pane configurations, however. Ceramic frits, etching, silk screening, and

\section{WTHOVI:}

Tinis paiblicly a valable po progam,

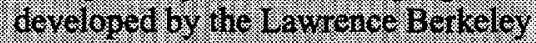
National Laboratosy allows his user to prodet thic themal properties (U-valuc

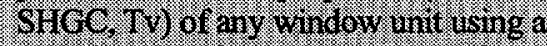
combiratron or commerctaly avaluble components. The progiram also ensures

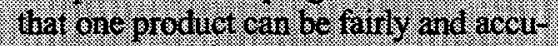

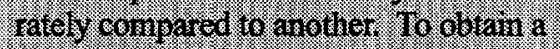

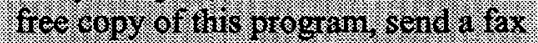
wh nane and adiress 10 WMDO We 4 at ( 510$) .486-4089$. In formation wat the

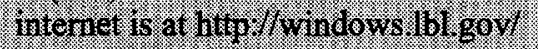

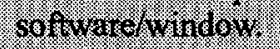

other glass patterns can be used for architectural design. Between-pane shading systems (venetian blinds, roller shades) may also be combined with spectrally selective glazings for improved energy performance.

\section{Installation}

Selective glazings can easily be substituted for conventional ones because design, construction, and installation are the same.

Coated and tinted glazings are applicable to any size window up to $\sim 3.3$ by $5.2 \mathrm{~m}(10.8 \times 17 \mathrm{ft})$-subject to wind loads. With window films, applicability may be limited to a glazing area less than $\sim 9.3 \mathrm{~m}^{2}\left(100 \mathrm{ft}^{2}\right)$; if the existing glass is highly absorptive (bronze tint) and/or an absorptive film is being applied, the increased thermal stress may cause the glass to break. Film manufacturers often offer warranties for breakage. Primary glazing manufacturers typically have no lead time on delivering the product to fabricators; window film manufacturers may have a four- to sixweek lead time for a large order and shorter lead time for a smaller order.

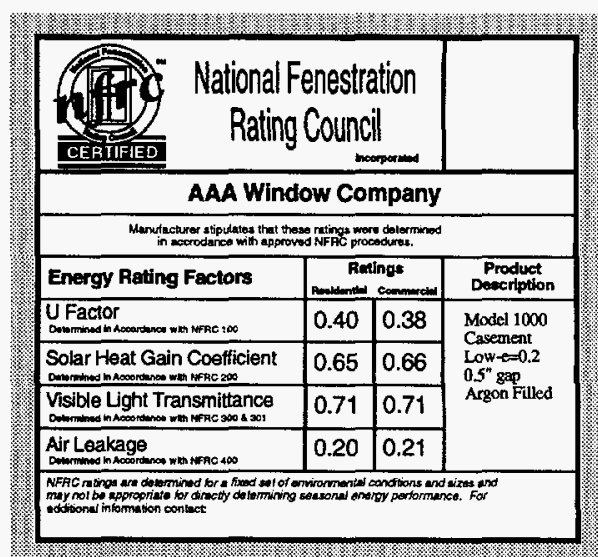

\section{National Renestration Rating Council (MTRe)}

The Natronal heriestration hating Councli (NRRC) vas, 6 ormed in

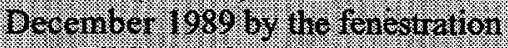

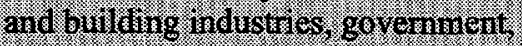

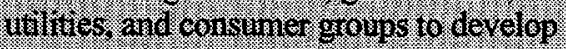

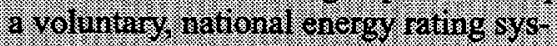
tem ior windows, divors, shylghts, and

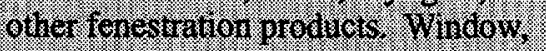

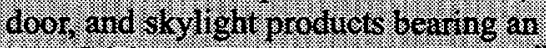
NIRC libel are concriered of merally

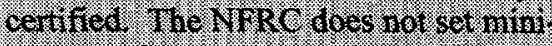
mun performance standards inst edd MFRC rangs show groduct gerfor: namee, so consumers can compare. proctuess and determine whether they

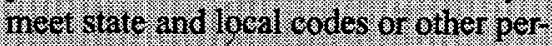
rommanice requirerancins:

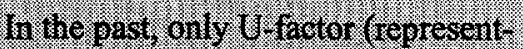

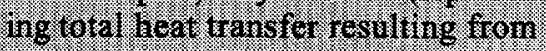
1ie remperature ifrerente betwcent the

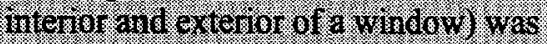

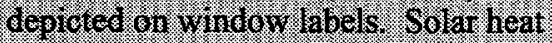
gan coef mcient ( $\mathrm{SHCO}$ ) and visible iransminance (t) t) dat a for more than 450 produdts are now a valable on latels

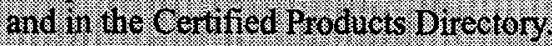

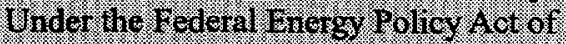
1992, the Ning wil, dung the next sercral years, nclide ratings of many. ofiler factors. Further wifomation can

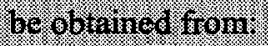

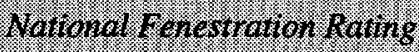

$0.017,01, .11 \%$

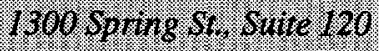

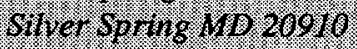

(801). 5.86 .6572

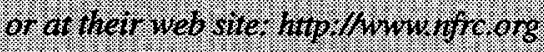


It is not possible to compile a complete list of all fabricators, distributors, and installers of spectrally selective products because hundreds of companies throughout the United States offer these products. However, all known original equipment manufacturers of the glass, coatings, and films are listed in the Manufacturers Section below. Other sources include the Thomas Register of American Manufacturers and the Sweet's Cata$\log$ File. Trade press journals such as Glass Digest, Glass Magazine, Fenestration, International Glass/ Metal Catalog, and Energy User News publish annual suppliers lists.

\section{Federal Sector Potential}

\section{Technology Screening Process}

Spectrally selective glazings are an energy-efficient technology with known energy, cost, and environmental benefits. A large number of manufacturers offer a variety of spectrally selective products. Spectrally selective glazings were chosen for the New Technology Demonstration Program through the Interlaboratory Council.

The New Technology Demonstration Program identifies new technologies from ideas submitted by Federal facility and energy managers. Technology ideas can also be submitted to the program through the FEMP web site. The technologies suggested were evaluated for potential Federal-sector energy savings and procurement,

NOTE: The NFRC gives data for the whole window, not just the glass. Data within this report are given for center-of-glass. installation, and maintenance costs. They were also categorized as new to the market ("unproved technologies") or as technologies for which field data already exist ("proven technologies").

\section{Estimated Savings and Market Potential}

Spectrally selective glazings have begun to penetrate the private residential and commercial markets but not the Federal sector. Manufacturers see key markets as the southern United States, but commercial sales growth has occurred in areas of high population or economic growth; the Pacific Northwest (Oregon and Seattle), Chicago, and throughout California, for example. Most residential sales activity has occurred in the "sunbelt" areas of the United States; activity has been increasing in "frost belt" regions. Spectrally selective glazings have been used worldwide in all types of buildings.

If Federal objectives were to reduce fossil fuel energy use, peak demand, and associated pollution, to improve occupant comfort and productivity, and to provide long-term (20- to 30-year) energy-efficient, sustainable technological solutions for reasonable life-cycle costs, then the Federal market potential for spectrally selective glazings would be immense. The Federal Government owns and leases approximately 500,000 buildings of various types of which 51,000 are office buildings containing approximately 1 to 2 billion $\mathrm{ft}^{2}$ of floor space. The Federal Government also owns an additional 422,000 housing units for military families (OTA 1991). Spectrally selective glazings can be justified as cost-effective and will provide energy and non-energy benefits for all of these buildings - and for virtually all buildings where occupants work near windows.

Opportunities for spectrally selective glazing are still quite substantial, particularly in the commercial sector, if decisions are made based only on operating cost savings resulting from energy and peak demand reductions and first cost savings resulting from reductions in chiller capacity. Spectrally selective glazing is most likely to prove cost-effective in buildings with large cooling loads, high utility rates, poor existing glazing, a large proportion of perimeter to core floor area, and/or buildings located in the southern United States. In the northern United States where buildings have both heating and cooling requirements, spectrally selective low-E systems are also cost-effective for cooling-load-dominated buildings such as offices.

To assess the performance of selective glazings, we determined annual building energy, peak demand, and cost savings for a commercial, internal-load-dominated building located in four representative climates in the United States (see Appendix B for detailed assumptions of this computer analysis). We compared the performance of six different types of glazings: 1) "historic" single-pane clear glass, 2) double-pane tinted bronze glass, 3) double-pane reflective glass, 4) double-pane tinted glass with a conventional low-E coating, 5) double-pane clear glass with a spectrally selective low-E coating, and 6) double-pane spectrally selective tinted glass with a spectrally selective low-E coating (Table 2). We also varied the window area from 
Table 2. Glazing Properties and Costs

\begin{tabular}{|c|c|c|c|c|c|c|c|}
\hline $\begin{array}{l}\text { Whadow: } \\
\text { fype: }\end{array}$ & Description: : & TY & sHoce & 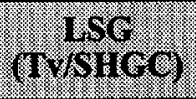 & $\begin{array}{l}\text { Uaractor } \\
\left(W / \mathrm{n}^{2}-2\right)\end{array}$ & 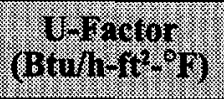 & 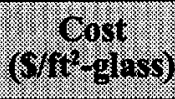 \\
\hline 1 & Single Clear & 0.88 & 0.83 & 1.06 & 6.17 & 1.09 & $\$ 2.50$ \\
\hline 2 & Double Bronze & 0.47 & 0.49 & 0.96 & 2.74 & 0.48 & $\$ 5.50$ \\
\hline 3 & Double Reflective & 0.13 & 0.17 & 0.76 & 2.35 & 0.41 & $\$ 7.00$ \\
\hline 4 & Double Low-E & 0.44 & 0.37 & 1.19 & 1.78 & 0.31 & $\$ 6.50$ \\
\hline 5 & Double Selective Tint & 0.41 & 0.28 & 1.46 & 1.64 & 0.29 & $\$ 8.00$ \\
\hline 6 & Double Selective Clear & 0.68 & 0.42 & 1.62 & 1.64 & 0.29 & $\$ 7.15$ \\
\hline
\end{tabular}

Notes:

- Cost data have been defined for a single pane or insulating glass unit with a heat treated exterior pane and an annealed interior pane. The curtainwall or building's window framing system costs are not included.

- Double low-E is defined as an exterior pane of conventional low-E coating on conventional tinted glass and an interior pane of clear glass in a double-pane unit.

- Double selective tint is defined as an exterior pane of spectrally selective low-E coating on selective tinted glass and an interior pane of clear glass.

- Double selective clear is defined as an exterior pane of spectrally selective low-E coating on clear glass and an interior pane of clear glass.

$15 \%$ to $60 \%$ of the exterior floor-tofloor wall area and modeled windows with an interior operable shade. Daylighting controls, used to automatically dim electric lights if sufficient daylight is available in a room, were also considered.

We computed two measures of performance: 1 ) cost-effectiveness measured in number of years to achieve a simple payback, and 2) peak demand reduction. The simple payback period was determined using energy data, glazing costs shown in Table 2, and a flat utility rate of $\$ 0.064 / \mathrm{kWh}$ for electricity and $\$ 0.36 /$ therm for heating. Existing or baseline glazings were compared against spectrally selective glass types 5 and 6 listed above; results are summarized in Tables 3 and 4. Key energy and cost trends evident from this analysis are:

- If no daylighting controls are used, then the glazing with the lowest solar heat gain coefficient (SHGC) will have the lowest annual energy use and peak demand (disregarding non-energy benefits such as view and daylight). See Figure 7a.

- If daylighting controls, such as automatic photosensor or manual controls, are used, then the glazing with the lowest SHGC and the highest visible transmittance (Tv) will have the lowest annual energy use and peak demand (Figure 7b). Selective glazings provide this energy advantage.

- Selective glazings with high daylight transmission are cost-effective in commercial buildings with relatively small glazing areas throughout the United States. (Table 3a). Selective glazings with moderate daylight transmission $(\mathrm{Tv} \approx 0.40)$ are cost effective in buildings with large glazing areas throughout the United States (Table 3b).

- Selective glazings will provide greater reductions in cooling load on sunward facing facades of the building (south, east, and west) and on windows unshaded by trees, overhangs, fins, or other exterior building obstructions.

- Selective glazing is most costeffective (payback less than 10 years) if used in cooling-loaddominated building types, in warmer climates, and with daylighting controls. In colder climates, like Madison, Wisconsin, these glazings are also cost-effective because spectral selectivity reduces cooling loads during the summer, and low emissivity and conductivity reduce heating loads during the winter.

- Selective glazings will pay back within 4 to 10 years for commercial buildings that currently have clear, single-pane or tinted, doublepane glass throughout most of the United States. Selective glazings will pay back within 4 to 10 years 
Table 3a. Cost-Effectiveness (simple payback in years) of Double Selective Clear (Type No. 6) IG Unit

\begin{tabular}{|c|c|c|c|c|c|c|c|c|c|c|}
\hline \multirow{2}{*}{\multicolumn{2}{|c|}{$\begin{array}{l}\text { Clunate } \\
\text { Daylighing Controls? }\end{array}$}} & \multirow{2}{*}{$\sqrt[3]{2}$} & \multicolumn{2}{|c|}{ madrou } & \multicolumn{2}{|c|}{203.4180103} & \multicolumn{2}{|c|}{ Mami } & \multicolumn{2}{|c|}{ Plochis } \\
\hline & & & tris & es: & No. & (1es: & & Thes & No. & Tes \\
\hline $\begin{array}{l}\text { Glass } \\
\text { Area* }\end{array}$ & Baseline Glazing & Type & & & & & & & & \\
\hline \multirow[t]{3}{*}{0.15} & Single Clear & 1 & 4 & 5 & 9 & +10 & 6 & 10 & 4 & 6 \\
\hline & Double Bronze & 2 & 7 & 4 & +10 & 5 & +10 & 4 & 8 & 4 \\
\hline & Double Low-E & 4 & +10 & 3 & - & 3 & - & 2 & - & 3 \\
\hline \multirow[t]{3}{*}{0.30} & Single Clear & 1 & 4 & 4 & 8 & 8 & 6 & 6 & 4 & \\
\hline & Double Bronze & 2 & 5 & 4 & +10 & +10 & +10 & 10 & 7 & 5 \\
\hline & Double Low-E & 4 & +10 & 7 & - & +10 & - & +10 & - & +10 \\
\hline \multirow[t]{3}{*}{0.45} & Single Clear & 1 & 4 & 4 & 8 & 8 & 6 & 6 & 4 & 4 \\
\hline & Double Bronze & 2 & 5 & 4 & +10 & +10 & +10 & +10 & 7 & 7 \\
\hline & Double Low-E & 4 & +10 & 10 & 一 & 一 & 一 & - & - & - \\
\hline \multirow[t]{3}{*}{0.60} & Single Clear & 1 & 4 & 4 & 8 & 8 & 6 & 6 & 4 & 4 \\
\hline & Double Bronze & 2 & 5 & 5 & +10 & +10 & +10 & +10 & 8 & 7 \\
\hline & Double Low-E & 4 & +10 & - & - & 一 & 一 & - & - & - \\
\hline
\end{tabular}

Table 3b. Cost-Effectiveness (simple payback in years) of Double Selective Tint (Type No. 5) IG Unit

\begin{tabular}{|c|c|c|c|c|c|c|c|c|c|c|}
\hline \multirow{2}{*}{\multicolumn{2}{|c|}{$\begin{array}{l}\text { Climate } \\
\text { Daylighing Controls? }\end{array}$}} & \multirow{3}{*}{$\frac{7}{7 y p e}$} & \multirow{2}{*}{\multicolumn{2}{|c|}{ Madilson: }} & \multicolumn{2}{|c|}{ Los angeles } & \multicolumn{2}{|c|}{ Mrim } & \multicolumn{2}{|c|}{ Phoenix } \\
\hline & & & & & 40 & Yes & $1 x_{0}$ & 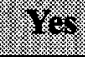 & No & 18 \\
\hline $\begin{array}{l}\text { Glass } \\
\text { Area* }\end{array}$ & Baseline Glazing & & & & & & & & & \\
\hline \multirow[t]{4}{*}{0.15} & Single Clear & 1 & 6 & +10 & +10 & 一 & 8 & +10 & 5 & +10 \\
\hline & Double Bronze & 2 & +10 & +10 & +10 & - & +10 & +10 & 8 & +10 \\
\hline & Double Low-E & 4 & +10 & - & +10 & 一 & +10 & +10 & +10 & +10 \\
\hline & Double Selective Clear & 6 & +10 & - & +10 & - & 7 & 一 & 6 & - \\
\hline \multirow[t]{4}{*}{0.30} & Single Clear & 1 & 5 & 5 & 8 & 10 & 6 & 7 & 5 & 5 \\
\hline & Double Bronze & 2 & 7 & 7 & +10 & +10 & 9 & 10 & 6 & 7 \\
\hline & Double Low-E & 4 & +10 & +10 & +10 & +10 & +10 & +10 & 9 & +10 \\
\hline & Double Selective Clear & 6 & +10 & - & 5 & +10 & 6 & +10 & 4 & 9 \\
\hline \multirow[t]{4}{*}{0.45} & Single Clear & 1 & 5 & 5 & 8 & 9 & 6 & 6 & 5 & 5 \\
\hline & Double Bronze & 2 & 7 & 7 & +10 & +10 & 9 & 9 & 6 & 6 \\
\hline & Double Low-E & 4 & +10 & +10 & +10 & +10 & +10 & +10 & 9 & 9 \\
\hline & Double Selective Clear & 6 & +10 & +10 & 5 & 6 & 5 & 5 & 4 & 5 \\
\hline \multirow[t]{4}{*}{0.60} & Single Clear & 1 & 5 & 5 & 8 & 8 & 7 & 6 & 5 & 5 \\
\hline & Double Bronze & 2 & 7 & 7 & +10 & +10 & 9 & 8 & 6 & 6 \\
\hline & Double Low-E & 4 & +10 & +10 & +10 & +10 & +10 & +10 & 9 & 9 \\
\hline & Double Selective Clear & 6 & +10 & +10 & 5 & 5 & 5 & 5 & 4 & 4 \\
\hline
\end{tabular}

Notes:

* Glass Area is defined as the percentage of glass area to exterior floor-to-floor wall area.

+10 Simple payback is greater than ten years.

- Baseline glazing outperformed spectrally selective glass.

- Glazings and cost for this analysis are the same as shown in Table 2.

- If daylighting controls were used, then the electric lights at the perimeter zone were dimmed if there was sufficient daylight. 
Table 4. Range of Peak Demand Reduction (W/ft ${ }^{2}$-floor) with Double Selective Clear (Type No. 6) IG Unit

\begin{tabular}{|c|c|c|c|c|c|c|c|c|c|c|}
\hline \multirow{2}{*}{\multicolumn{2}{|c|}{$\begin{array}{l}\text { Chimate } \\
\text { Baylighiting Controls? }\end{array}$}} & \multirow{2}{*}{ 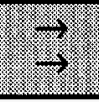 } & \multicolumn{2}{|c|}{ Madison } & \multicolumn{2}{|c|}{ Ios $A$ ingeles } & \multicolumn{2}{|c|}{ Mranin } & \multicolumn{2}{|c|}{ Phoonix } \\
\hline & & & 10: & Yes & No & Tes: & No & Yes & & Tes: \\
\hline $\begin{array}{l}\text { Glass } \\
\text { Area* }\end{array}$ & Baseline Glazing & Type & $\mathbf{W} / \mathbf{f t}^{2}$ & $\mathbf{W} / \mathbf{f t}^{2}$ & $\mathbf{W} / \mathbf{f t}^{2}$ & $\mathbf{W} / \mathbf{f t}^{2}$ & $\mathbf{W} / \mathbf{f t}^{2}$ & $\mathbf{W} / \mathbf{f t}^{2}$ & $W / f^{2}$ & $\mathbf{W} / \mathbf{f t}^{2}$ \\
\hline \multirow[t]{5}{*}{0.15} & Single Clear & 1 & $\begin{array}{r}0.56 \\
\text { to } 0.88\end{array}$ & $\begin{array}{r}0.51 \\
\text { to } 0.84\end{array}$ & $\begin{array}{r}0.71 \\
\text { to } 1.01\end{array}$ & $\begin{array}{r}0.64 \\
\text { to } 0.98\end{array}$ & $\begin{array}{r}0.53 \\
\text { to } 0.96\end{array}$ & $\begin{array}{r}0.47 \\
\text { to } 0.84\end{array}$ & $\begin{array}{r}0.86 \\
\text { to } 1.14\end{array}$ & $\begin{array}{r}0.75 \\
\text { to } 1.11\end{array}$ \\
\hline & Double Bronze & 2 & 0.07 & 0.12 & 0.09 & 0.12 & 0.05 & 0.12 & 0.17 & 0.11 \\
\hline & & & 0.15 & 0.16 & 0.20 & 0.21 & 0.20 & 0.13 & 0.25 & 0.27 \\
\hline & Double Low-E & 4 & 0 & 0.04 & -0.04 & -0.02 & -0.02 & 0.02 & -0.03 & -0.01 \\
\hline & & & -0.05 & -0.03 & -0.07 & -0.03 & -0.02 & 0.02 & -0.05 & -0.03 \\
\hline \multirow[t]{6}{*}{0.30} & Single Clear & 1 & 1.40 & 1.44 & 1.46 & 1.47 & 1.31 & 1.31 & 1.79 & 1.73 \\
\hline & & & 1.87 & 1.89 & 1.94 & 2.01 & 1.84 & 1.86 & 2.33 & 2.31 \\
\hline & Double Bronze & 2 & 0.27 & 0.31 & 0.28 & 0.30 & 0.29 & 0.31 & 0.43 & 0.41 \\
\hline & & & 0.40 & 0.42 & 0.37 & 0.39 & 0.34 & 0.37 & 0.59 & 0.54 \\
\hline & Double Low-E & 4 & -0.02 & -0.01 & -0.12 & -0.09 & -0.06 & -0.06 & -0.07 & -0.05 \\
\hline & & & -0.11 & -0.10 & -0.15 & -0.13 & -0.15 & -0.13 & -0.07 & -0.08 \\
\hline \multirow[t]{6}{*}{0.45} & Single Clear & 1 & 2.02 & 2.03 & 2.21 & 2.26 & 2.05 & 2.08 & 2.6 & 2.61 \\
\hline & & & 2.65 & 2.66 & 3.05 & 3.10 & 2.77 & 2.71 & 3.41 & 3.44 \\
\hline & Double Bronze & 2 & 0.44 & 0.45 & 0.40 & 0.41 & 0.40 & 0.39 & 0.65 & 0.63 \\
\hline & & & 0.59 & 0.58 & 0.53 & 0.56 & 0.43 & 0.39 & 0.86 & 0.86 \\
\hline & Double Low-E & 4 & -0.06 & -0.05 & -0.17 & -0.16 & -0.07 & -0.12 & -0.07 & -0.08 \\
\hline & & & -0.15 & -0.16 & -0.23 & -0.24 & -0.24 & -0.28 & -0.11 & -0.12 \\
\hline \multirow[t]{6}{*}{0.60} & Single Clear & 1 & 2.56 & 2.56 & 2.95 & 3.00 & 2.72 & 2.70 & 3.33 & 3.36 \\
\hline & & & 3.39 & 3.38 & 3.79 & 3.19 & 3.51 & 3.50 & 4.29 & 4.34 \\
\hline & Double Bronze & 2 & 0.58 & 0.57 & 0.52 & 0.54 & 0.58 & 0.55 & 0.84 & 0.87 \\
\hline & & & 0.79 & 0.78 & 0.66 & 0.72 & 0.69 & 0.67 & 1.07 & 1.08 \\
\hline & Double Low-E & 4 & -0.07 & -0.08 & -0.22 & -0.22 & -0.10 & -0.21 & -0.10 & -0.11 \\
\hline & & & -0.21 & -0.24 & -0.43 & -0.38 & -0.42 & -0.38 & -0.20 & -0.22 \\
\hline
\end{tabular}

Notes:

* Glass Area is defined as the percentage of glass area to exterior floor-to-floor wall area.

- Rarge defined by upper and lower number in Table. For example, for Madison with no daylighting controls, peak demand reductions achieved by the double selective clear glass compared to the single clear glass are 0.56 to $0.88 \mathrm{~W} / \mathrm{ft}^{2}$ of perimeter floor area. If a value is negative, the baseline glazing outperformed the selective glazing.

- Absolute peak values are given in Figure 7 and in Tables 1 and 2 of Appendix C.

for some commercial buildings in the southern United States if the baseline glazing is low-emissivity, double-pane windows. ${ }^{(b)}$
- In this analysis, first-cost savings associated with downsized mechanical systems (resulting from reductions in peak demand)

(b) Note that there is great variability in "cost-effectiveness" depending on how one defines the baseline glazing. Choosing a low-E glass with slightly different characteristics can change these results substantially (especially with respect to the 10-year payback criterion), so these results should be regarded carefully.

were not incorporated in the cost savings equation; these savings may reduce the payback period.

Appendix $\mathrm{C}$ provides detailed data from the simulation work above for those who wish to draw analogies to their specific buildings. For specific applications in commercial buildings, an hour-by-hour building energy simulation program, such as DOE-2 

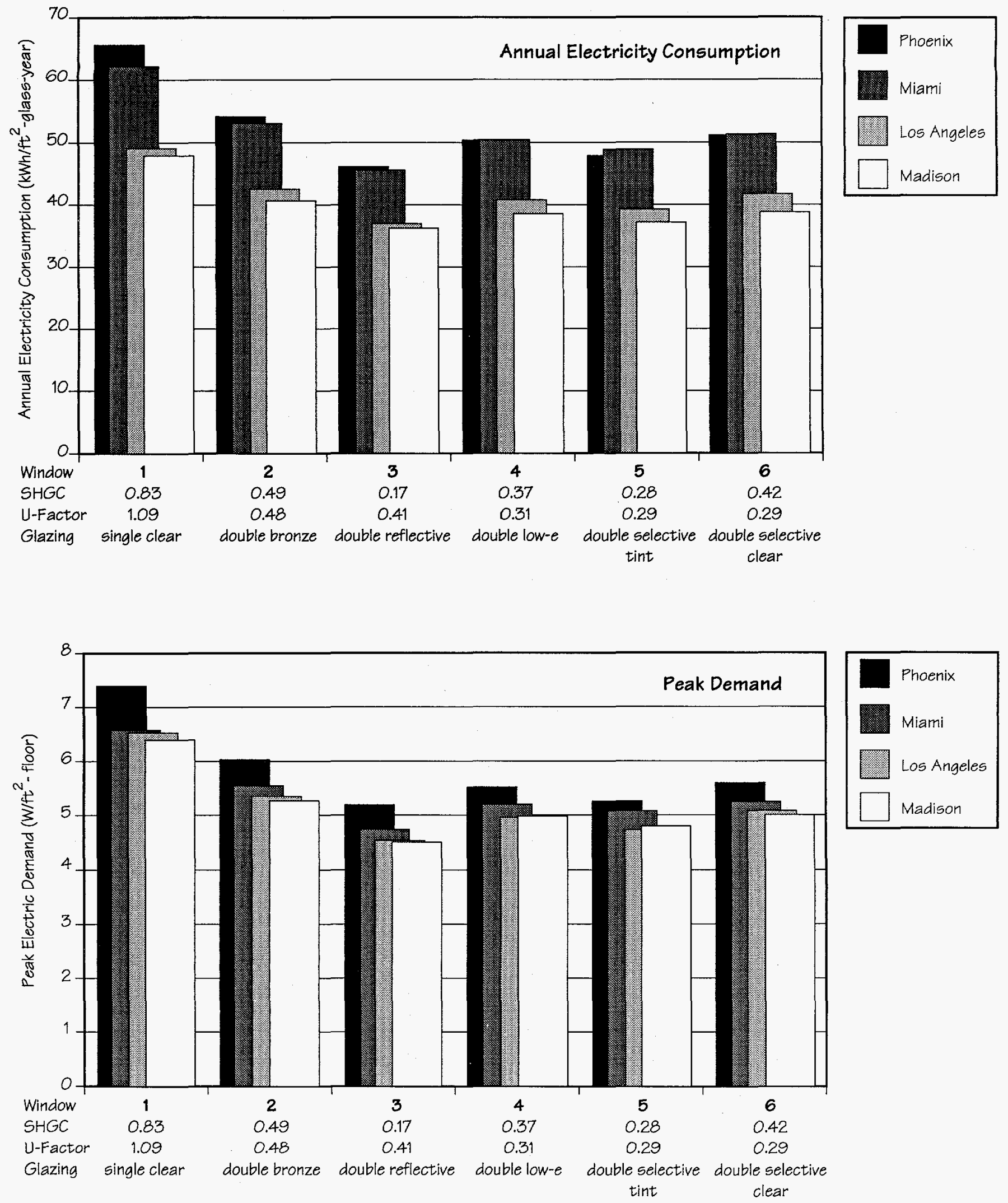

Figure 7a. Annual Electricity Consumption and Peak Demand for Six Different Glazing Types and No Daylighting Controls (Results are given for a glazing area that is $30 \%$ of the exterior wall area.) 

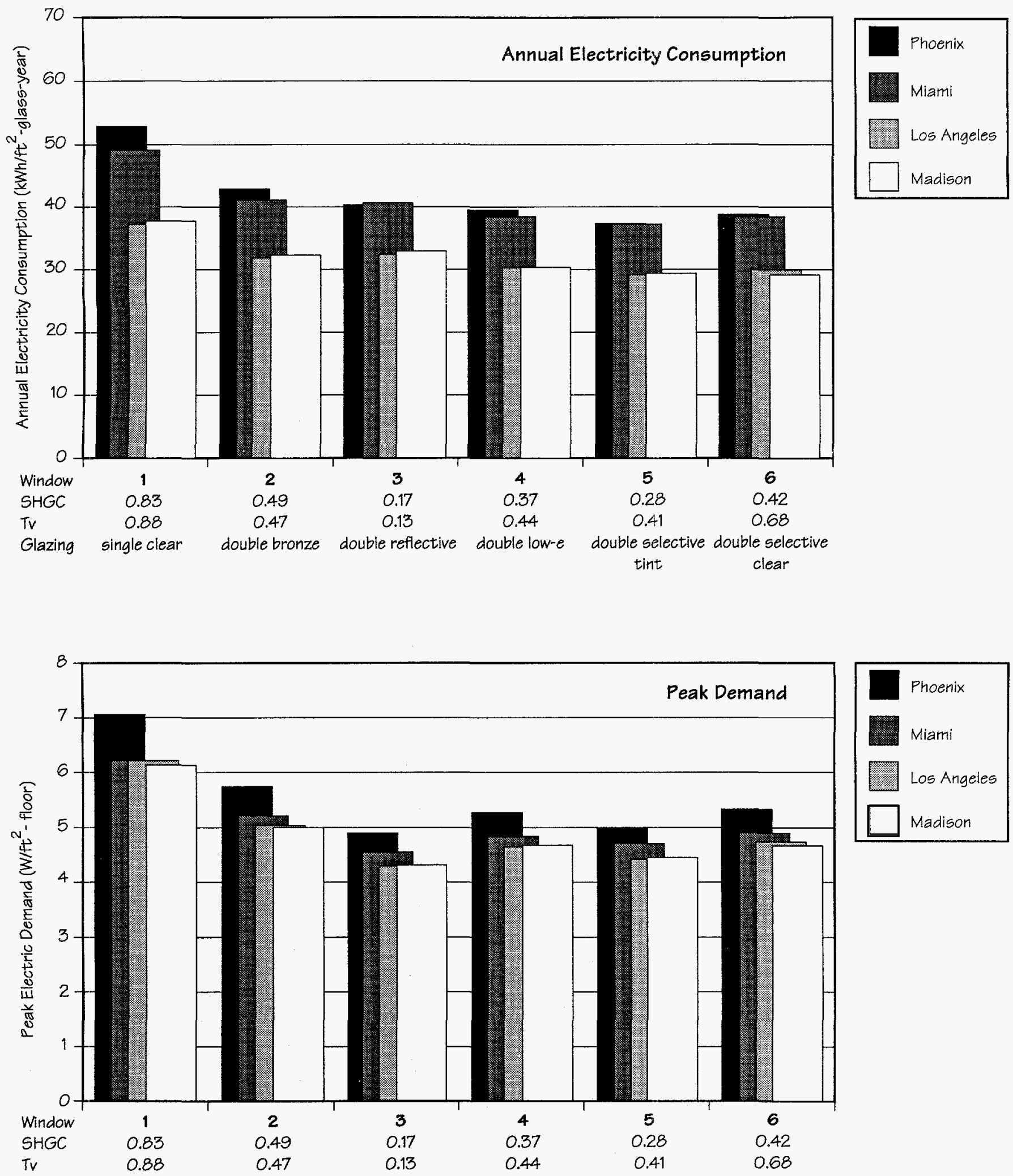

Glazing single clear double bronze double reflective double low-e double selective double selective tint clear

Figure 7b. Annual Electricity Consumption and Peak Demand for Six Different Glazing Types with Daylighting Controls (Results are given for a glazing area that is $30 \%$ of the exterior wall area.) 


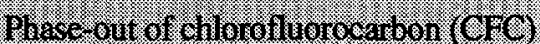
renger ant in tie Rederal sector will

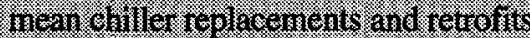

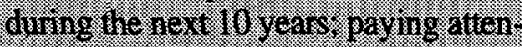
tor to possubulitics tor loducing peal

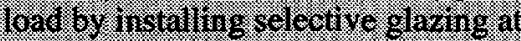
the vane wine thilers are replaced could herease erergy and economic beneths

(see "For Further Information"), which uses hourly weather data and can model the thermodynamics of advanced window systems, will provide more accurate estimates.

\section{Laboratory Perspective}

Laboratory testing, field testing, and theoretical analysis have shown that spectrally selective glazings are technically valid, reliable, and economically attractive in many applications (Klems et al. 1995; Lee et al. 1993; Gueymard and McCluney 1992). The primary barriers to full market penetration of this technology are 1) building design decision makers lack of knowledge about spectrally selective glazings and 2) the perception that these glazings are expensive. In addition, energyefficiency and occupant comfort are often not weighted as highly as a building's exterior appearance in the design process for new construction. In retrofits, however, building managers may appreciate the benefits of high-performance windows because of complaints related to the existing windows: occupants who experience discomfort at the perimeter zones, high utility bills particularly during peak cooling periods, and/or high vacancy rates for spaces where the glazing causes discomfort. The incremental premium for spectrally selective glass may seem negligible in relation to these problems.
Budgets for building-wide window replacement are difficult to justify on the basis of energy payback alone. For windows older than 15-20 years, property managers can use repair and alteration funds to defray retrofit costs. For new windows with poor performance, property managers must consider alternatives such as interior shades, window films, or solar screens because the cost of full replacement is difficult to justify against other competing energy-efficiency technologies that involve replacing isolated equipment such as lamps or motors. To address this market barrier, educational programs such as this Federal Technology Alert can provide critical information to all decision makers in the building design process.

\section{Application}

\section{Application Screening}

Most commercial buildings can reduce cooling costs and increase occupant comfort by lowering solar heat gain, so selective glazing produces easy energy savings. A selective glazing can also mean only a subtle tint to windows when a highly reflective glass would otherwise be necessary to achieve the same performance, or clear glazing when a tint would otherwise be necessary. For cooling-dominated commercial buildings in mild to hot climates, property managers can identify a potential application by observing complaints from perimeter-zone occupants (too hot even during the winter despite a functional mechanical system), use of personal fans and space heaters in individual offices, or high utility bills that track hot, sunny weather. If the building is heavily shaded by exterior solar window screens, trees, buildings, or other obstructions, however, the benefits of spectral selectivity may not be fully achievable.

The transparency of selective low-E coatings is a major advantage for sunbelt residential applications where solar control is important and heavily tinted or mirrored glazings are undesirable.

\section{Where to Apply}

- The benefits from spectrally selective glazings are greater in buildings that are cooling dominated or both cooling and heating dominated (e.g., office and similar spaces, atria, etc.) and where utility rates are high.

- For retrofit applications, buildings with clear, reflective or dark-tinted windows will benefit from spectrally selective glazings. Buildings with clear, single-pane glass are prime candidates for spectrally selective glazing retrofits, either through addition of control films or replacement of glazing with laminated glass or IG units.

- Buildings undergoing renovation, including replacement of window glass and/or window frames, are good candidates for spectrally selective glazing. A buildingspecific energy analysis can determine the applicability of spectrally selective glazings.

- Buildings undergoing mechanical system renovation are also good candidates for spectrally selective glazing. Upgrade of the window system and mechanical system should be integrated because large peak load reductions derived from the window upgrade will reduce the required system capacity. 
- Buildings where occupants complain about excessive heat during summer months may be good candidates for spectrally selective glazings.

- Situations where sensitive articles are stored may benefit from reduced temperature fluctuations provided by spectrally selective glazing's control of solar heat gains.

\section{What to Avoid}

Spectrally selective products may not be applicable in the following situations.

- Heating-load-dominated buildings with small or no cooling requirements.

- Unoccupied buildings that are not air conditioned, such as warehouses and storage facilities, or naturally ventilated buildings, such as workshops with open doors or windows.

- Buildings with exterior shading devices, such as blinds, overhangs, and shade trees. These buildings may not benefit from spectrally selective glazings. If lowtransmission exterior shading devices are already in place, selective glazings will probably not be beneficial. However, if these exterior devices are poorly designed, obstruct view, or need to be replaced, selective glazings can provide comparable heat gain control and increase occupants' feelings of connection to the outdoors.

- Buildings with existing singlepane low-E windows. Applying spectrally selective films over the existing windows will eliminate the low-emissivity properties of the previous coating; selective films with low-E properties should be used in this situation.

- Buildings where there is glare from windows during daylight hours, especially on computer screens. In these buildings, glare may be increased if high-Tv spectrally selective glazings replace existing low-Tv glazings, such as darkly tinted windows. Although occupants may enjoy new clear views, architectural solutions may be needed to mitigate glare.

- Wet, humid, corrosive, or abrasive conditions with use of plastic retrofit films. These conditions may cause coating failure, edge degradation, or delamination of plastic retrofit window films after five years. Bubbling and edge degradation is less likely for typical interior environments because window film adhesives have significantly improved over the years. Poor film installation techniques (e.g., application over dirty glass) can degrade the view and overall appearance of the window system as well. Attention should be paid to the terms of the film manufacturer's warranty.

\section{Equipment Integration}

As noted above, use of spectrally selective glazing can substantially reduce building loads and peak demand. Because sizing of mechanical systems is typically based on peak load, there may be opportunities to downsize chiller capacity if selective glazings are introduced. Building operators may find that the decreased load resulting from addition of spectrally selective glazing may cause an existing HVAC system to run at a lower point of its part-load efficiency curve.

\section{Maintenance Impact}

Maintenance requirements for spectrally selective windows are essentially the same as for conventional windows. Installations using sealed IG units (double- or triplepane) require no extra care because the spectrally selective coating is inside the IG unit and not exposed to abrasion from cleaning or weather. Window films may scratch if abraded and so should be cleaned with care. Additional maintenance costs are negligible for most applications.

\section{Warranties}

Window manufacturers typically guarantee selective glazings in the same manner as conventional glazings. For tinted glass, there is no special warranty needed against chemical degradation because the tint is an inherent part of the glass. For spectrally selective low-E and window film products, manufacturers often guarantee coatings against peeling, degradation, or defects for a period of 10 years.

\section{Codes and Standards}

Many states have adopted the American Society of Heating, Refrigerating, and Air Conditioning Engineers (ASHRAE) 90.1 energy code standard, which acts as a guideline for commercial energy code legislation. 
The easiest of three methods of compliance with this standard are the Prescriptive Criteria, which often force designers to choose smaller window area for lower heat loss. Alternate methods of compliance involve computer analysis, which is more complex but generally allows larger window area. Residential energy codes are structured in a similar manner.

With codes and standards, commercial buildings must often achieve solar gain by a darkened view or reflective appearance to windows. Spectrally selective glazings give architects more options for window design with fewer tradeoffs.

\section{Costs}

- Costs in this document are given per square foot of glazing area, not per square foot of floor area.

- For new commercial construction, the incremental materials cost for use of a selective coating versus a standard low-E coating is $\$ 2.70$ to $5.40 / \mathrm{m}^{2}\left(\$ 0.25\right.$ to $\left.\$ 0.50 / \mathrm{ft}^{2}\right)$, which includes an average $30 \%$ markup added by local distributors.

- If selective tinted glazings are used, the incremental materials cost between clear glass and an excellent selective tinted glass can be $\$ 17.75 / \mathrm{m}^{2}\left(\$ 1.65 / \mathrm{ft}^{2}\right)$, which includes an average $30 \%$ markup added by local distributors.

- For comparison purposes, Table 2 gives materials costs for a variety of generic commercial IG units for a volume of approximately $2,787 \mathrm{~m}^{2}\left(30,000 \mathrm{ft}^{2}\right)$ including markup. For smaller volumes, the materials cost may increase by 10 to $15 \%$ or more. For larger volumes, price breaks may be given by some dealers.

- Glass manufacturers sell the raw glass or film product to fabricators who process the glass to produce laminates, window films, or full window products (IG units, wood windows with frames, etc.). These products are distributed to local representatives or general contractors. The materials cost of a final window unit will vary depending on quantity of units, unit sizes, and mix of sizes purchased by the customer, the perception of the local representative of the desirability of certain window attributes, and the customers' willingness to pay for these attributes. Therefore, the materials cost of commercial and residential windows varies locally.

- The incremental installation cost for selective products rather than nonselective products in new construction is zero. For retrofit situations, the incremental cost is zero if window replacement or improvements were already planned.

- For estimation purposes, the total cost for materials and installation is $\$ 65$ to $160 / \mathrm{m}^{2}$ ( $\$ 6$ to $15 / \mathrm{ft}^{2}$ ) for glass in new and retrofit construction, and $\$ 30$ to $130 / \mathrm{m}^{2}$ ( $\$ 3$ to $12 / \mathrm{ft}^{2}$ ) for window film in retrofit construction. Expect to pay $\$ 15$ to $30 / \mathrm{m}^{2}$-glass $\left(\$ 1.50\right.$ to $3.00 / \mathrm{ft}^{2}$ glass) for removal of the film after $\sim 10$ to 15 years. Installation costs are subject to local labor charges, market pace, and the logistics of installation at each particular building site. For retrofit situations, difficult access to the windows from the interior, moving of furniture, removal of window coverings, removal of material on the windows (dirt or stickers for window film applications), or work during swing, graveyard, or weekend hours can increase costs.

\section{Utility Incentives and Support}

At present, there are no direct rebates or incentive programs that support market transformation for selective glazing; however, many indirect incentive programs promote its use. Many utilities give cash rebates for each $\mathrm{kW}$ of demand reduced or deferred, engineering assistance or energy audits to help customers analyze design options, shared savings or $0 \%$ financing, customer services (workshops, billing services, etc.), or system commissioning assistance. These incentives are typically provided if certain criteria are met, e.g., if energy codes are exceeded or demand is reduced in major renovations or new construction. Often a utility requires that the demand reduction be measurable, verifiable, and permanent. Monitoring of demand reduction from windows will require supplementary simulations because window-related loads cannot be measured directly (unlike equipment plug loads).

Many rebates do not account for synergy among building systems. Selective glazing energy reductions are tied to the lighting control and 
mechanical systems, but equipment replacement rebates are usually made separately for these systems. Programs promoting envelope measures or rewarding performance options for load shedding, load management, or exceeding baseline code requirements should be investigated for the possibility that they may indirectly support spectrally selective glazings.

A customized approach is sometimes available where rebates are based on actual energy savings regardless of the technology employed. Utility representatives can give information on custom incentive programs.

A list of the latest utility incentives throughout the United States and Canada is given annually in Energy User News. Also, publications or surveys may be available from the Electric Power Research Institute (EPRI) at (800) 525-8555.

\section{Technology Performance}

For detailed discussions of field experiences with recent installations of spectrally selective glazing, see the case studies in the next section. Energy savings and maintenance issues are covered there as well. Interestingly, comments from users focus on aesthetics and comfort. Some anecdotal comments made by users of the technology include:

"The selection of the glass was extremely important for the building to meet stringent energy code requirements. Recent development of highly sophisticated glass and glazing systems permit high transparency with excellent solar shading performance. The energy consumption for HVAC, heating, and cooling and lighting is expected to be $1,058 \mathrm{kWh} / \mathrm{m}^{2}-\mathrm{yr}(38,900$ $\mathrm{Btu} / \mathrm{ft}^{2}-\mathrm{yr}$ )-only $65 \%$ of the suggested norm."

- Architect and mechanical engineer for the Seattle Museum of Flight, which has $8,361 \mathrm{~m}^{2}\left(90,000 \mathrm{ft}^{2}\right)$ of glass on all four walls of an exhibit hall displaying full-size aircraft and more than $\$ 14 M$ worth of aviation artifacts.

"We wanted clear glass to make the hotel's lobbies open and natural, yet we needed the shading protection of dark glass. Too much heat from the sun would overtax the hotel's air-conditioning system.... The shading and insulating capabilities of selective glazings compared to any other glass available looked too good to be true. Because of lower airconditioning demands, the extra cost compared to other options will be paid back within a year."

\section{- Project Manager, Marriott} Hotel, Palm Desert, California.

"The theater's dramatic, enclosed lobby can be enjoyed by patrons throughout the day and into the evening."

- Architect of a movie theater in Universal City, California with $1,180 \mathrm{~m}^{2}\left(12,700 \mathrm{ft}^{2}\right)$ of barrel-vaulted skylights in the lobby.

"An environment composed of pools, waterfalls and plants is like having a huge humidifier going all the time. We wanted to include the view from this location as a major design feature of the building. Considering the cold weather Colorado experiences, that view could be ruined much of the time by condensation on the windows. We were asked to design a system that would not allow any condensation on the windows. It would be expensive to use a typical heating and cooling system to accomplish this. Our solution to designing a cost-effective system that would meet all the design criteria was to use a type of glass that lets in light while controlling heat and condensation. According to our calculations, this building will save more than $\$ 4,000$ annually compared with conventional double-paned windows, and no condensation will form on the windows even when the outside temperature is below $-18^{\circ} \mathrm{C}\left(0^{\circ} \mathrm{F}\right)$."

- Mechanical engineer of a glass-walled recreation center in Westminster, Colorado, with $1,208 \mathrm{~m}^{2}\left(13,000 \mathrm{ft}^{2}\right)$ of glass walls and skylights.

"The ability to achieve clear, natural lighting at acceptable levels was our greatest concern. Ordinary clear glass would permit too high an intensity of light into six new galleries - as high as 9,688 lux (900 fc) in May or June. Dark glass would reduce the light intensity, but would add unwanted color to the natural light."

\section{- Architect of Chicago Art} Institute's 12,077 $\mathrm{m}^{2}(130,000$ $\mathrm{ft}^{2}$ ) exhibit hall for 19th and 20th century American Paintings and European decorative arts. 
"High insulating value and the capability to reflect unwanted heat gain in a clear, colorless glass were considered valuable, both in terms of energy savings as well as aesthetics."

- Representative of the development's owners of a seven-story office building and 145 condominiums for the National Wildlife Federation and Resources for the Future in Washington, D.C.'s Historic District.

\section{Case Studies}

Case studies are presented for different types of spectrally selective products in new and retrofitted Federal facilities. Case studies using products that best fit our definition of spectral selectivity (see EnergySavings Mechanism Section) are presented first, for new and retrofitted Federal facilities.

\section{New U.S. Courthouse}

Tucson, Arizona

\section{Double-pane Clear Glass with a Spectrally Selective Coating}

The new showcase Federal Building and U.S. Courthouse located in downtown Tucson, Arizona is now under construction and due to be completed by December 1999 . The L-shaped building consists of two six-story towers connected by a curved atrium and walkway with a total gross floor area of $39,000 \mathrm{~m}^{2}$ $\left(419,000 \mathrm{ft}^{2}\right)$ and an occupiable floor area of $24,000 \mathrm{~m}^{2}\left(257,000 \mathrm{ft}^{2}\right)$. On the south and west facades, an aluminum curtain wall and corrugated metal form a staggered exterior shading system in front of the windows; on the north and east, strip and punched windows with smaller area are used.
The windows for this building consist of insulating glass units that have an exterior pane of clear glass with a spectrally selective coating for excellent daylight transmission and solar heat gain rejection, and an interior pane of laminated clear glass to meet new 1997 courthouse security standards. The coating exhibits a sharp cut-off in transmission between the visible and infrared portion of the solar spectrum and thus is $30 \%$ more effective than standard low-E coatings at decreasing solar heat gains. The glass was selected by the architectural team for its clear, non-tinted appearance and for its ability to improve occupant comfort while reducing building energy consumption. Although this building uses an energy savings performance contract (ESPC) for other energyefficiency measures, the glazing choice was part of the baseline building. A separate life-cycle analysis for the glazing was not done. The center-of-glass properties are: $\mathrm{T} v=0.70$, $\mathrm{SHGC}=0.37$, U-factor $=1.59 \mathrm{~W} / \mathrm{m}^{2}$ ${ }^{\circ} \mathrm{K}\left(0.28 \mathrm{Btu} / \mathrm{h}-\mathrm{ft}^{2}{ }^{\circ} \mathrm{F}\right), \mathrm{LSG}=1.89$.

Contact: Mark Levi, Government Services Agency (GSA) Building Management Specialist, (415) 522-3374.

\section{Case Studies Using Spectrally Selective Suspended Film}

The following Federal facilities have employed a spectrally selective film suspended between two glass surfaces in an IG unit:

- Ordnance Damage Control Laboratory, Yorktown, Virginia, 1985.

- U.S. Coast Guard Facility Design and Construction, Norfolk, Virginia, 1985.
- Buckley Naval Reserve Training Center and Air National Guard Base, Aurora, Colorado, 1986.

- U.S. Federal Courthouse, Wichita, Kansas, 1987.

- U.S. Post Office, Johns Island, North Carolina, 1987.

\section{New U.S. Courthouse}

Sacramento, California

Selective Tinted Glass with

\section{Conventional Low-E Coating}

The $69,000 \mathrm{~m}^{2}\left(741,000 \mathrm{ft}^{2}\right)$ new Sacramento Courthouse was completed in December 1997. It consists of a 16-story tower containing courtrooms, and a four-story entrance pavilion with a skylit rotunda. The masonry tower has a bowed glass curtain wall with floor-to-ceiling full-height windows and no exterior shading. The window system consists of a spectrally selective aqua-greentinted glass with a conventional low-E coating on the exterior glass pane and an interior clear laminated glass pane. The center-of-glass properties are: $\mathrm{Tv}=0.35, \mathrm{SHGC}=0.22$, U-factor $=1.87$ $\mathrm{W} / \mathrm{m}^{2}-^{\circ} \mathrm{K}\left(0.33 \mathrm{Btu} / \mathrm{h}-\mathrm{ft}^{2}-^{\circ} \mathrm{F}\right), \mathrm{LSG}=1.61$.

Contact: Mark Levi, GSA Building Management Specialist, (415) 522-3374.

\section{New U.S. Courthouse}

Tampa, Florida

\section{Conventional Tinted Glass with Conventional Low-E Coating}

The Sam M. Gibbons U.S. Courthouse is a new building adjacent to the existing Timberlake Federal Complex in the central business district of Tampa, Florida; it was completed in September 1997. The 17-story rectangular tower contains $35,400 \mathrm{~m}^{2}\left(382,000 \mathrm{ft}^{2}\right)$ gross floor area. 
A unique, well-integrated building envelope design addresses the admission of comfortable filtered daylight to displace lighting energy use while controlling direct sun and solar heat gains. The design does not rely solely on the glazing to mitigate solar heat gain; the west facade of the building uses exterior aluminum and concrete horizontal and vertical sunshades to control direct sun. Other facades have recessed the windows to control direct sun. Photoelectric sensors control the electric lighting response to daylight in the perimeter zones. Transom windows are used to daylight the $3.25-\mathrm{m}-(10.5-\mathrm{ft})$ high perimeter tenant spaces.

The windows employ a conventional low-E coating on a conventional green-tinted exterior glass pane with a clear interior glass pane forming an insulating glass unit. With its exterior sunshades, the overall envelope performance is substantially better than one with unshaded glazing; the architect predicts net cooling load savings of 10.6 tons per floor compared to the load with unshaded, uninsulated, monolithic glazing. The center-of-glass properties are: $\mathrm{Tv}=0.43, \mathrm{SHGC}=0.28$, $\mathrm{U}$-factor $=1.93 \mathrm{~W} / \mathrm{m}^{2}{ }^{\circ} \mathrm{K}(0.34 \mathrm{Btu} /$ $\left.\mathrm{hr}-\mathrm{ft}^{2}{ }^{\circ} \mathrm{F}\right), \mathrm{LSG}=1.54$.

Contact: Brian Kimsey, GSA, for design information at (404) 331-5330 or Joe Marinaccio, GSA Project Manager at (404) 331-4238.

\section{Retrofit of Federal Building}

Tucson, Arizona-Detailed Case Study

Conventional Tinted Glass with Conventional Low-E Coating

The Tucson Federal Building is a $11,240 \mathrm{~m}^{2}\left(121,000 \mathrm{ft}^{2}\right)$ seven-story rectangular tower with a larger twostory base partially below grade. The building was completed in 1974 and is located in the central business district of Tucson, Arizona. The average yearly temperature is $20.2^{\circ} \mathrm{C}$ $\left(68.4^{\circ} \mathrm{F}\right)$, with diumal variations of 3.9 to $17.8^{\circ} \mathrm{C}\left(39\right.$ to $64^{\circ} \mathrm{F}$ ) in the winter and 23.3 to $37.8^{\circ} \mathrm{C}$ (74 to $100^{\circ} \mathrm{F}$ ) in the summer, and record temperatures of $47^{\circ} \mathrm{C}\left(117^{\circ} \mathrm{F}\right)$. There are 117 cooling degree days (base $\left.18^{\circ} \mathrm{C}, 65^{\circ} \mathrm{F}\right)$ and 16 heating degree days. Solar gains will dominate the peak building load (as with the new Las Vegas Courthouse described below); average global incident solar radiation on a south-facing surface is $3,941 \mathrm{Wh} / \mathrm{m}^{2}(1250 \mathrm{Btu} /$ $\mathrm{ft}^{2}$-day).

The precast concrete building envelope has large, fixed-frame, aluminum windows that are $1.8 \mathrm{~m}$ (6-ft) high and $3.0 \mathrm{~m}(10-\mathrm{ft})$ wide with two $1.52-\mathrm{m}(5-\mathrm{ft})$ sections per bay. Each window is recessed from the facade by $\sim 0.6 \mathrm{~m}(\sim 2 \mathrm{ft})$, so there is partial horizontal and vertical shading of the window from direct sun. Interior, beige, $7.6-\mathrm{cm}$ (3-in) opaque vertical blinds are installed at each window. No significant shading occurs from adjacent buildings or trees surrounding the structure one to two city blocks away.

Degrading exterior solar window screens were removed from the building for safety reasons in July 1995. These screens had covered $100 \%$ of the window surface and consisted of bronze aluminum horizontal slats 1.6-mm (0.0625-in) wide, spaced $1.6 \mathrm{~mm}(0.0625 \mathrm{in})$ apart. The tilt angle of the slats was designed to be changeable; however, the angle was left in a slightly downward position (ground view from the interior).
The building manager noted that the screens were a maintenance problem (they had to be removed and replaced for window washing) and gave occupants a blurred view of the outdoors.

The glazing was single-pane, 6-mm $(0.25$-in) bronze tinted glass $(\mathrm{Tv}=0.21, \mathrm{SHGC}=0.39, \mathrm{U}$-factor $=6.2$ $\left.\mathrm{W} / \mathrm{m}^{2}{ }^{\circ} \mathrm{K}\left(1.1 \mathrm{Btw} / \mathrm{h}-\mathrm{ft}^{2}-{ }^{\circ} \mathrm{F}\right), \mathrm{LSG}=0.54\right)$. When the exterior window screens were removed, the property manager received numerous complaints about the window heat load from occupants in the building's perimeter zonesabout a 10 to $15 \%$ increase in complaints, especially in winter when the sun angle was low. Tinted glass controls solar heat gains through absorption, so the interior surface of the glass tends to get quite hot, causing thermal discomfort to those nearby. The two-pipe fan coil unit under each window (controlled by a Johnson Controls Medisys system, hot or cold only, installed in 1994) supplied air conditioning but was inadequate to counter the increased load from the hot interior surface of the glass. About 10 windows broke per year from heat stress after the screens were removed. The cooling load (and utility operating cost) of the building also increased significantly as a result of removal of the screens.

The 23-year-old windows also showed signs of degradation and needed to be replaced. The property manager set design criteria for the new window system: 1) provide a good solar control solution that is inherent in the glass to minimize maintenance and operations costs (e.g., for window washing), 2) reduce thermal discomfort of the occupants, 3) reduce the cooling load and operating costs, 4) maintain the existing bronze color, if possible, 
but don't darken the view, and 5) use the existing aluminum window frames. Tucson Electric Power Administration was commissioned to do a preliminary audit and analysis of the building. The property manager reviewed trade magazines and manufacturer's catalogs and obtained samples of several glazing types. He experimented with different types of solar screens and glass types at full scale. He also consulted with the Technical Section of the Regional Government Services Agency (GSA) Building Services Branch to determine energy-efficiency options and means to fund the renovation. The Lawrence Berkeley National Laboratory's Windows and Daylighting Group was asked to review the final glazing performance specifications and to discuss options with the property manager. The performance specifications set minimum glass characteristics of: SHGC $\leq 0.22$, $\mathrm{Tv} \geq 0.32$, U-factor $=1.42-1.87 \mathrm{~W} / \mathrm{m}^{2}-^{\circ} \mathrm{K}$ $\left(0.25-0.33 \mathrm{Btu} / \mathrm{h}-\mathrm{ft}^{2}-^{\circ} \mathrm{F}\right)$, and $\mathrm{LSG}=\mathrm{Tv} /$ SHGC $>1.44$.

During the bidding process, one general contractor suggested a tinted green glass to meet the performance specifications. The property manager visited a nearby building where the glass was installed. His original preference for bronze glass to keep the building appearance the same shifted when he saw the bright interior views and the more natural color rendition of the exterior landscape through the tinted green glass; in contrast, the bronze glass gave a smoggy appearance to the view. The glass selected was an IG unit consisting of 6-mm conventional green-tinted exterior pane with a conventional low-E coating, an air gas fill, and a 6-mm clear interior pane. The center of glass properties are:
$\mathrm{Tv}=0.43, \mathrm{SHGC}=0.28, \mathrm{U}$-factor $=1.93$ $\mathrm{W} / \mathrm{m}^{2}-^{\circ} \mathrm{K}\left(0.34 \mathrm{Btu} / \mathrm{hr}-\mathrm{ft}^{2}-{ }^{\circ} \mathrm{F}\right), \mathrm{LSG}=1.54$. The IG units were installed with a replacement glass stop, to accommodate the wider $2.5-\mathrm{cm}$ (1-in) thickness, and caulked with silicone sealant. Johnson Controls, consultant project manager for Tucson Electric Power and GSA, had put out a request for proposals in early August 1996. The job was completed in April 1997 at a cost of $\$ 161 / \mathrm{m}^{2}$-glass $\left(\$ 15 / \mathrm{ft}^{2}\right.$-glass) including materials, installation, overhead, profit, and bond. A life-cycle cost analysis was not required by the contract; however, an analysis was done using DOE-2 simulations and the Federal Building Life-Cycle Cost (BLCC) program issued by the National Institute for Standards and Technology (NIST). See Appendix D for a printout from this analysis. The installation was done with the building completely occupied, and with essentially no complaints from occupants. Some interior partitions attached to the window mullions had to be removed and replaced, but this was completed smoothly with no impact on the schedule.

Quantifying energy savings with actual metered data is difficult because cooling energy loads from window systems alone cannot be measured directly (in contrast, for example, to energy consumption of lighting equipment which can easily be measured with a watt transducer). One must be able to isolate changes in energy use patterns produced by the selective glazing from other changes to the building, e.g., increased occupancy, new equipment, or other upgrades to the building. To draw statistically significant conclusions, whole-building utility data must be collected for at least a six-month period, preferably during the summer, when only the window system has been changed. Because there were changes in the Tucson Federal Building's mechanical system, occupancy, and plug loads between the previous year and during the few months following the completion of the window retrofit, there are no "clean" monitoring data from which to draw significant conclusions.

Prior to installation of the spectrally selective glazing, the property manager had to resort to several strategies to try to avoid being charged for demand beyond the utility baseline. He used an off-the-grid emergency generator at times and had a plateframe heat exchanger installed on the evaporative cooling tower, so he could avoid using the building's 200-ton York chiller during some periods. Tucson charges $\$ 6.66 / \mathrm{kW}$ over $200 \mathrm{~kW}$ usage per month and $\$ 0.066 / \mathrm{kWh}$ for electricity use. In June following the retrofit, the building manager began to notice changes that suggested improvements in building energy performance. He changed the mechanical system start time to one hour later than previous operation because demand had reduced substantially. He also reduced the lock on the chiller limit from $80 \%$ to $70 \%$. In mid-July 1997 with outdoor temperatures of $37.8^{\circ} \mathrm{C}\left(100^{\circ} \mathrm{F}\right)$, he was able to run his chiller at $74 \%$, down from $80 \%$ in 1996. In addition, he took side-by-side measurements of the new and old glazing interior surface temperature glass on a hot day. The bronze glass in full sun was $49^{\circ} \mathrm{C}\left(120^{\circ} \mathrm{F}\right)$ while the new glass was only $34.4^{\circ} \mathrm{C}\left(94^{\circ} \mathrm{F}\right)$, a $14.6^{\circ} \mathrm{C}\left(26^{\circ} \mathrm{F}\right)$ temperature difference. Many building occupants have remarked on the brighter view and 
more comfortable conditions since the new green-tinted glass was installed.

Contact: Cecilia Serrano, GSA Senior Property Manager, (520) 670-4738, Ron Sandlin, GSA Property Manager, (520) 670-4738, or Bruce Tanner, GSA Chief Engineer, (520) 670-4748.

\section{Window Films, Oakland Federal Building}

The Oakland Federal Building consists of two 18-story towers connected by a five-story glass rotunda, totaling $99.87 \mathrm{~km}^{2}\left(1.075 \mathrm{Mft}^{2}\right)$ gross floor area. The office building has been $\sim 95 \%$ occupied since 1992 and is located in downtown Oakland, California. Annual electricity consumption is $11,125 \mathrm{MWh} /$ year at an annual cost of $\$ 1,091,000$ given the Pacific Gas and Electric Company (PG\&E) time-of-use rate schedule. Annual natural gas consumption is 96,000 therms/year at an annual cost for heating and domestic hot water of $\$ 56,640$.

The window system consists of 6-mm (0.25-in) single-pane conventional tinted green glass $(\mathrm{Tv}=0.75$, $\mathrm{SHGC}=0.60, \mathrm{U}$-factor $=5.44 \mathrm{~W} / \mathrm{m}^{2}-^{\circ} \mathrm{K}$

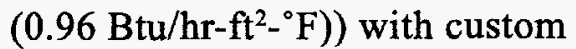
aluminum frames. A typical window rough opening has a width of 4.57 to $7.62 \mathrm{~m}(15$ to $25 \mathrm{ft})$ and a height of $2.74 \mathrm{~m}(9 \mathrm{ft})$, with divided lights ranging in width from 0.91 to $1.52 \mathrm{~m}$ ( 3 to $5 \mathrm{ft}$ ). The window glazing is recessed 0.15 to $0.41 \mathrm{~m}(0.5$ to 1.33 $\mathrm{ft}$ ) from the face of the building and has mullions that are $0.13 \mathrm{~m}$ ( $5 \mathrm{in}$.) deep on the interior and $2.5 \mathrm{~cm}$ (1 in.) deep on the exterior. Double-pane glazing was initially specified in the building but was taken out because of "value engineering," concern for keeping first costs low.
Steps to select and evaluate spectrally selective glazing options

The following procedure is a guide to determining the cost-efteetiveness of selec. tive glazings over conventional glazings. See the "Other Benefits" section of this report, and incopporate a cost for non-energy benefits (e.g. loss of productivity. tenant absenteeisinj if possible. Softuare programs are listed in the section Tor Further thformation:

1) Choose selective glazing products based on the following simple center-of glass criteria:

a) 1 :SC $\rightarrow$ TVISHCC $>1.25$ or greater.

6. Tr> 0.40 for increased view and connection to the outdoons:

c) Winimize SHGC for decreased solar heat gains and ait-conditioning loads and for increased thermal comfort.

d) $\mathrm{l}$-factor-1 $42-1.87 \mathrm{~W}_{\mathrm{m}}^{2}-\mathrm{K}\left(025-0.33 \mathrm{Bm} / \mathrm{h}-\mathrm{f}^{2}-\mathrm{F}\right)$

Consul manufacturer S product liferature or the NIREC Certified Ptoducts Directory for these specifications. These guidelines are given for center of glass only: not whole window performance.

2) Consult with the nariufacturer for exact window properties for a given building? window size: shape. frame constriction glass type, and gas fill. If the nanufac turer does not provide hils service, use WIINDO W4 1 to determine exnet window properties.

3) Buid an input deseription of the building for DOE-2 or comparable program. Include WINDOW 4 ourput dara. Model exrenor and interior shading conditions and day highting strategles. Alow the nechanical systern to be sized automatically by the program in order to determine IVAC downsizing opportunities. Run separate calculations for baseline and selective glazings where only the glazing type is changed (do not inelude with other energy-effictency strategies):

4) Investigate cooling. lighing, and heating energy reductions for the perimeter: zones ony (do not include core zonc) - Break redictions down by window. ortentation. Do the same for peak demand reductions and relate to HVAC capacity reductions.

5) Determine simple payback for a quick cheok of eost effectiveness. Muluply. energy savings by an average flat unity rate or use builtin cconomics nodiles of DOFH 2 to catculate energy savings for time-of-use rate structures.

Divide ammal energy cost saving by the glazing area. Divide be neremental: cost of the spectrally selective glass (materals only) by the amnal cost savings: per glazing arca to arrive at pay back period: Include savings from downisizing the air-conditioning system or chillet if applieable.

6) Run the Federal Buiding Life Cycle Cost (BLCC) software progtam issued by tise National Thstitute for Standards and Techiology (NIST), to determine If cycle cost payback:

For residential applications, use the RFSFEN program, a WINIDOWS-based PC program for calculating residential fenestration heating and cooling energy use and cosst. Also consult the National Fenestration Rating Council (NFRC) for a list of: all residential window products and their comparable thermal and solar properties.

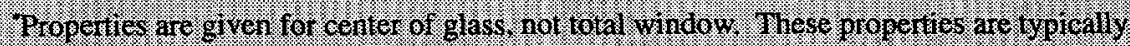
given in manurequrer s calalogs. WWDOW4 computes hese properties for the entre Whidow systern. Which tends to be lover in perromance lian the cencer of ghass. 
Consideration of window films was undertaken in response to complaints from tenants that occupy the south tower and because of large energy and demand utility bills. Tenants complained that the space was too hot or too cold, especially for those occupying the south- and west-facing perimeter offices during the summer. The property manager noticed a large increase in energy use during the summer and deduced that the cause was increased cooling load because of heat gains through the single-pane glazing. Demand increased by $50 \%$ and electricity consumption increased $22 \%$ from the winter to the peak summer months. On a moderate $24^{\circ} \mathrm{C}\left(75^{\circ} \mathrm{F}\right)$ day, one 450-ton chiller was running at part load to serve the entire building. On a hot sunny day $\left(32-39^{\circ} \mathrm{C}, 90\right.$ to $100^{\circ} \mathrm{F}$ ), one 450 -ton chiller and one 1,000-ton chiller were operating at maximum load. Yet Oakland's climate is fairly mild; ASHRAE design dry-bulb temperatures are $32.8^{\circ} \mathrm{C} /$ $91^{\circ} \mathrm{F}(0.1 \%)$ and $25^{\circ} \mathrm{C} / 77^{\circ} \mathrm{F}(2.0 \%)$.

The criteria for window film selection were (a) to minimize the reflectivity of the window film and its impact on the building appearance, and (b) to ensure the highest quality implementation for tenant satisfaction.

The building owner wanted to use GSA funds for the energy retrofit, which are provided through the Federal Buildings Fund. To qualify for these funds, an energy-efficiency retrofit must be cost-effective with a life-cycle cost payback of 10 years or less, determined by the BLCC program. See Appendix $\mathrm{E}$ for more information. Projects throughout the nation bid competitively for these funds; projects with shorter paybacks are typically implemented first.
Estimates of annual energy requirements must be available for BLCC analysis. Typically, a Federal building energy manager will rely on the window manufacturer to provide these data. Performance data $(\mathrm{TV}$, SHGC, etc.) for films applied to generic glazing types (e.g., clear, tinted, double-pane) can be obtained in manufacturer product literature. For properties of the film-glass assembly in a particular building, manufacturers can provide property managers with data using the LBNL WINDOW 4.1 program. Utility rebate/incentive programs sometimes offer comprehensive performance analysis services; however, at the time, the local utility, Pacific Gas and Electric (PG\&E), offered prescriptive rebates for window films with specific performance properties; for east, south, and west facing windows, films with a minimum Tv of 0.50 , a maximum SHGC of 0.61 , and a ratio of Tv to SHGC greater than 1.15 were to be rebated at $\$ 4.84 / \mathrm{m}^{2}\left(0.45 / \mathrm{ft}^{2}\right)$ of installed window film.

The property manager researched various window film products, installed several in full-scale installations on various windows to evaluate the building's appearance, and obtained an energy analysis ${ }^{(c)}$ performed by the manufacturer. The window manufacturer estimated total energy savings at $\$ 7 / \mathrm{m}^{2}$-glass-yr for the north facade and $\$ 20 / \mathrm{m}^{2}$-glass-yr for the south, with a simple payback of two years for the south, east, and west facades, and five years for the north facade. Exterior shading was

(c) The Association of Industrial Metalizers Coaters and Laminators, Inc. (AIMCAL) FACTS program (call (602) 951-3997) is a simple PC program that calculates the cost and energy benefits of window films. not accounted for, and interior shading was considered negligible, so these payback estimates may be generous. The suggested window film, a combination of tinted gray film over a reflective film, had centerof-glass properties of $\mathrm{Tv}=0.13$ and SHGC $=0.25$ installed on the existing glass. Material and labor costs were estimated at $\$ 37.67 / \mathrm{m}^{2}$-film $(\$ 3.50$ / $\mathrm{ft}^{2}$-film). Costs for removal 10 to 15 years later were estimated at $\$ 16$ to $21.50 / \mathrm{m}^{2}$-film ( $\$ 1.50$ to $2.00 / \mathrm{ft}^{2}$-film) in today's cost terms, but these were not factored into the analysis.

The energy savings were based only on reduction in the building's cooling load and so were directly proportional to reduction in solar heat gain coefficient. However, the building also has stepped daylighting controls, so lighting energy use would be affected by reduced daylight transmission. The Tv of 0.13 proposed by the manufacturer was very low and would dampen exterior views, including the building's spectacular south and west views of the San Francisco Bay area.

The Lawrence Berkeley National Laboratory ran a preliminary DOE2.1E building energy simulation analysis for the Oakland Federal Building with a number of window film, shading, and lighting control options. The payback periods for the window films were found to be roughly comparable to those generated by the manufacturer's analysis, except for the north facade, which showed a payback of nine years. For a selective, low-E window film with high daylight transmission $(\mathrm{Tv}=0.58$, $\mathrm{SHGC}=0.46$, $\mathrm{LSG}=1.26$ ), the payback period was increased to eight to 10 years for the east, west, and south facades and to 20 years for the north facade. If 
interior and exterior shading and electric lighting controls are considered, the simple payback becomes 11 to 20 years for all facade orientations. Interior, perforated, white, vertical, louver blinds are employed on all windows.

Several types of window films were considered. The slightly reflective, dark window film would change the exterior building appearance and impair views (reflective films obscure night views). Dark absorptive films with little reflectivity would increase occupants' thermal discomfort. The films with higher Tv would provide more daylight and a connection to the outdoors but had a long payback (eight to 10 years), which reduced the project's chances of qualifying for GSA funding because GSA funds for energy-efficiency projects are allocated to those with the shortest paybacks. Given these limitations, the property manager was unable to choose among the types of window film, so no film was installed.

This case study illustrates the consequences of "value engineering" or selecting exterior glazing systems simply to reduce first costs. A glazing system has a 20 - to 30-year life and directly affects the comfort of employees (the highest paid employees often have window offices and thus suffer greatest discomfort). Glazing problems are very difficult to remedy once a building is built. For the added cost of the window film retrofit, the best spectrally selective insulating glass unit could have been installed from the start, avoiding loss in productivity and comfort and with no increase in operating costs. A reduction in original HVAC capacity could also have been factored in to justify increased cost of the selective glazing when the building was constructed.
Contact: Edgar Gray, GSA Property Manager, (510) 637-5000.

\section{The Technology in Perspective}

Conventional blue- or green-tinted glazings have been available commercially since the 1960 s but have more recently been "tuned" to achieve higher selectivity. Sputtered, silverbased, multilayer, selective, low-E coatings were developed and commercialized in the early 1980 s. A wide range of durable and reliable selective products exists for any type of window application in the United States.

The optical properties of these glazings should continue to improve during the next 5 to 10 years as material scientists push theoretical limits with new engineered coatings that are cheaper and easier to manufacture. If a good durable coating is developed that does not need the protected environment of an IG unit, then spectrally selective single-pane units could be more widely used. In addition, selective tinted glazings may eventually include colors other than the blue-green family. As conventional low- $E$ coatings have transformed the window market of the 1980 s, we anticipate that selective low-E coatings will do the same during the 1990 s and beyond.

\section{Manufacturers}

AFG Industries
Mark Sullivan
AFG Industries
P.O. Box 929
Kingsport TN 37662
phone: $615 / 357-2450$
fax: $615 / 357-8858$

\section{Cardinal IG}

Mike Tourville

Cardinal IG

12301 Whitewater Dr. Minnetonka MN 55426 phone: $612 / 932-6602$

fax: $612 / 935-5538$

\section{Dupont Polymers}

\section{Ray Foss}

Dupont Polymers

P.O. Box 1217

Parkersburg VA 26102

phone: 304/863-4355

fax: $304 / 863-2681$

\section{Ford Motor Company}

Lowell Rager

Ford Motor Company

Glass Division

Fairlane Business Park

17333 Federal Drive, Suite 230

Allen Park MI 48101

phone: $313 / 845-5788$

fax: $313 / 845-5986$

\section{Guardian Industries}

Karl Straky

Guardian Industries

14600 Romine Road

Carleton MI 48117

phone: $313 / 654-4332$

fax: $313 / 654-0935$

\section{Interpane}

Donald Cheshek

Interpane Glass Company

950 East 133 rd Drive

Thornton CO 80241-1141

phone: 303/452-9667, x323

fax: 303/452-1159

\section{Libbey-Owens-Ford Co.}

Paul Gore

Libbey-Owens-Ford Co.

811 Madison Ave., P.O. Box 799

Toledo OH 43697-0799

phone: $419 / 247-4833$

fax: $419 / 247-4517$ 
Monsanto

Claude Duquette

Monsanto

730 Worcester Street

Springfield MA 01151

phone: $413 / 730-2614$

fax: 413/730-3394

MSE Specialty Films

Dave Swaggerty

\section{MSE Specialty Films}

4540 Viewridge Road

San Diego CA 92123

phone: 800/736-1836, 1272

fax: $619 / 576-8519$

PPG Industries

Patrick Kenny

PPG Industries, Inc.

One PPG Place

Pittsburgh PA 15272

phone: 412/434-2616

fax: $412 / 434-3675$

Southwall Technologies

Dave Jones

Southwall Technologies

1029 Corporation Way

Palo Alto CA 94303

phone: $415 / 962-9115 \times 123$

fax: 415/967-0182

\section{M Construction Markets}

James Mannix

$3 \mathrm{M}$ Construction Markets

Bldg. 224-45-08

$3 \mathrm{M}$ Center

St. Paul MN 55144

phone: $612 / 733-2222$

fax: $612 / 736-0611$

\section{Viracon}

Laura Dalland

Viracon

800 Park Drive

P.O. Box 990

Owatonna MN 55060

phone: $800 / 533-0482, \times 3189$

fax: $507 / 455-4290$

\section{For Further Information}

\section{Organizations}

American Architectural

Manufacturing Association

(AAMA)

1827 Walden Office Square, St.

120

Schaumburg IL 60173-4268

phone: $847 / 303-5664$

fax: $847 / 303-5774$

\section{Association of Industrial}

Metalizers, Coaters, and

Laminators, Inc.

211 N. Union Street, Suite 100

Alexandria VA 22314

phone: 602/951-3997

Energy Efficiency and Renewable

Energy Clearinghouse (EREC) 800/DOE-EREC

Energy Efficiency and Renewable

Energy Network (EREN)

(for Internet access to FEMP

documents)

http://www.eren.doe.gov

Federal Energy Management Program (FEMP)

Help Line: 800/DOE-EREC

\section{Florida Solar Energy Center}

(FSEC)

\section{Clearlake Road}

Cocoa FL 32922-5703

phone: $407 / 638-1000$

fax: $407 / 638-1010$

Illuminating Engineering Society of North America

120 Wall Street

New York NY 10005-4001

phone: $212 / 248-5000$

fax: $212 / 248-5017$
Lawrence Berkeley National Laboratory (LBNL)

Building Technologies Program

1 Cyclotron Road, MS 90-3111

Berkeley CA 94720

phone: 510/486-6845

fax: 510/486-4089

http://windows.lbl.gov

National Fenestration Rating

Council, Inc. (NFRC)

1300 Spring Street, Suite 120

Silver Spring MD 20910

phone: $301 / 589-6372$

http://www.nfrc.org.

\section{Primary Glass Manufacturers}

Council (PGMC)

3310 Harrison Street

Topeka KS 66611-2279

phone: 913-266-3666

fax: $913-266-0272$

Sealed Insulating Glass

Manufacturers Association

(SIGMA)

401 N. Michigan Avenue

Chicago IL 60611

phone: $312 / 644-6610$

fax:312/527-6783

\section{Software}

\section{Window 4.1}

This program calculates total window properties from individual component data (glass panes, gas fill, frames). To obtain a free copy of this program, send a fax with name and address to WINDOW4 at (510) 486-4089. In addition, there is access to information via the internet at http://eande.lbl.gov/BTP/therm.html.

\section{Applied Film Laminator}

This program calculates combined glass and film properties from spectral data of individual layers. To obtain 
a free copy of this program, send a fax with narne and address to Applied Film Laminator at (510) 486-4089.

\section{DOE-2 and RESFEN Energy} Analysis Software.

These programs simulate building energy use, a useful way to compare energy-efficient alternatives, estimate energy costs, perform life-cycle cost analysis, determine code compliance, estimate peak power demands, disaggregate energy end uses, andmost commonly-compute loads for HVAC equipment sizing. A partial list of energy simulation software includes the following (not all model daylighting or show code compliance):

*DOE2.1E

Lawrence Berkeley National

Laboratory

(510) 486-5711

*RESFEN ${ }^{4}$

National Fenestration Rating

Council

(301) 589-NFRC

*ADM-DOE2

ADM Associates

(916) 363-8383

\section{*CEDDOEDC}

California Energy Commission (916) 654-5106

*DOE24/Comply-24

Gabel-Dodd Associates

(510) 428-0803

*DOE-Plus

ITEM Systems

(206) 382-1440

*PRC-DOE2

Partnership for Resource

Conservation

(303) 499-8611
*Micro DOE2

Acrosoft International

(303) 696-6888

*Visual DOE2.0 for Windows

Eley \& Associates

(415) 957-1977

BLAST

BLAST Support Office

(800) 842-5278

Trace 600

The Trane Company

(608) 787-3926

HAP

Carrier Corporation

(800) 253-1794

ASHRAE/IESNA Stnd.90.1

Compliance \& ASHRAE

Publications

(800) 527-4723

*For a list of software companies selling versions of DOE2, contact LBNL.

\section{Literature}

Manufacturer Technical Literature and Product Representatives are free sources of information and assistance. Product choices and suppliers can be identified in Sweets Catalog starting with section 08810. Many of the brochures in the section contain useful general information on glazing in addition to productspecific data. Most manufacturers will readily supply samples (typically 12 " by $12^{\prime \prime}$ or smaller) and copies of their Sweets brochures. Some manufacturers will also perform energy calculations.

\section{Books}

There are only a few up-to-date materials available on glazing. The best source for timely information may be the architectural journals, which occasionally run glazing articles in their technical sections.

Residential Windows - A Guide to New Technologies and Energy Performance by John Carmody, Stephen Selkowitz, and Lisa Heschong (W.W. Norton, 1996) is a good concise book on window technologies, their implications for residential design, and their appropriate specification.

Building Technologies Program Publications: http://eande.lbl.gov/ BTP/pub/papers.html.

"Tips for Daylighting with Windows" is a quick reference for designers using a set of easy steps and rules of thumb, emphasizing "how-to" practical details: http://eande.lbl.gov/ BTP/pub/designguide.

A well-written, concise document, "Energy Management Program Window Film Training Guide," explaining window film products is distributed by the Association of Industrial Metalizers Coaters and Laminators, Inc. (AIMCAL). In this document, non-energy benefits of window films are cited, such as improved shatter resistance, reduced fading of interior furnishings because of low ultraviolet light transmission, creation of desired privacy, creation of a uniform exterior building facade appearance, balancing of hot and cold spots in the building, increased tenant comfort, and reduced glare. Other information is also given, such as what films are composed of, what 
the definitions are for various solar properties, how long films will last, how windows with films should be cleaned, whether films kill house plants, whether window films can be used on low-E windows, and what may cause glass breakage.

\section{References}

Arasteh, D. 1995. "Advances in Window Technology: 1973-1993." Lawrence Berkeley National Laboratory Report LBL-36891, Berkeley, CA.

Arasteh, D., R. Johnson, and S. Selkowitz. 1986. "Definition and Use of a Daylight 'Coolness' Index." 1986 International Daylighting Conference Proceedings II.

Arasteh, D., D. Connell, and S. Selkowitz. 1986. "The Effect of Daylighting Strategies on Building Cooling Loads and Overall Energy Performance." ASHRAE Transactions 91(1).

ASHRAE. 1997. ASHRAE Handbook - Fundamentals, Chapter 27, Fenestration. American Society of Heating, Refrigerating, and AirConditioning Engineers, Inc.
Gueymard, C. and R. McCluney. 1992. "The Potential of Electric Load Reductions Obtained in Hot Humid Climates from Office Buildings using Efficient Electric Lighting, High Performance Glazings and Daylighting." Proceedings of the ACEEE 1992 Summer Study on Energy Efficiency in Buildings (1): 89-100. FSEC-PF-242-92, Florida Solar Energy Center (FSEC).

Johnson, T. E. 1991. Low-E Glazing Design Guide. Boston: Butterworth Architecture.

Klems, J.H., M. Yazdanian, G.O Kelley. 1995. "Measured Performance of Selective Glazings." Proceedings of the Thermal Performance of the Exterior Envelopes of Buildings VI, Clearwater Beach, FL, December.

Lee, E.S., D. Hopkins, M. Rubin, D. Arasteh, and S. Selkowitz. 1994. "Spectrally Selective Glazings for Residential Retrofits in CoolingDominated Climates." ASHRAE Trans. 100 (1) 1994. Lawrence Berkeley National Laboratory Report LBL-34455, Berkeley, CA.

McCluney, R. 1993. "Choosing the Best Window for Hot Climates." Proceedings of the Innovative Housing '93 Conference, Vancouver, B.C., June. FSEC-PF-253-93, Florida Solar Energy Center (FSEC).
McCluney, R. 1991. "The Physics of Angularly and Spectrally Selective Window Glazings: A Tutorial Introduction." FSEC PF-227-91, Florida Solar Energy Center (FSEC).

OTA. 1991. "Energy Efficiency in the Federal Government: Government by Good Example?" U.S. Congress, Office of Technology Assessment. OTA-E-492. U.S. Government Printing Office. Washington, DC. May.

Schuman, J. 1992. Technical Focus: Cool Daylight. Progressive Architecture 4.92:136-141.

Sullivan, R., D. Arasteh, G. Sweitzer, R. Johnson, and S. Selkowitz. 1987. "The Influence of Glazing Selection on Commercial Building Energy Performance in Hot and Humid Climates." Proceedings, ASHRAE Conference on Air Conditioning in Hot Climates, Singapore.

Sullivan, R. and S. Selkowitz. 1986. "Residential Heating and Cooling Energy Cost Implications Associated with Window Type." ASHRAE Transactions 93(1):1525-1539.

Sweitzer, G., D. Arasteh, and S. Selkowitz. 1986. "Effects of LowEmissivity Glazings on Energy Use Patterns in Nonresidential Daylighted Buildings." ASHRAE Transactions 93(1):1553-1566. 


\section{Appendixes}

Appendix A: Properties of Spectrally Selective Glazings for Nonresidential and Residential Applications Appendix B: Energy Performance Analysis

Appendix C: Energy, Peak Demand, and Cost Data from the Simulations

Appendix D: Federal Life-Cycle Cost Analysis

Appendix E: Federal Life-Cycle Costing Procedures and the BLCC Software 


\section{Appendix A \\ Properties of Spectrally Selective Glazings for Nonresidential and Residential Applications}

To give an idea of the number of spectrally selective products and options available for particular building applications, we show the center-of-glass visible transmittance (Tv) and solar heat gain coefficient (SHGC) properties for commercially available glazing products. Graphs are presented for nonresidential and residential markets for single-, double-, and triple-pane products. Data are from the NFRC Certified Products Directory (November 1996).

\section{Non-Residential Applications}

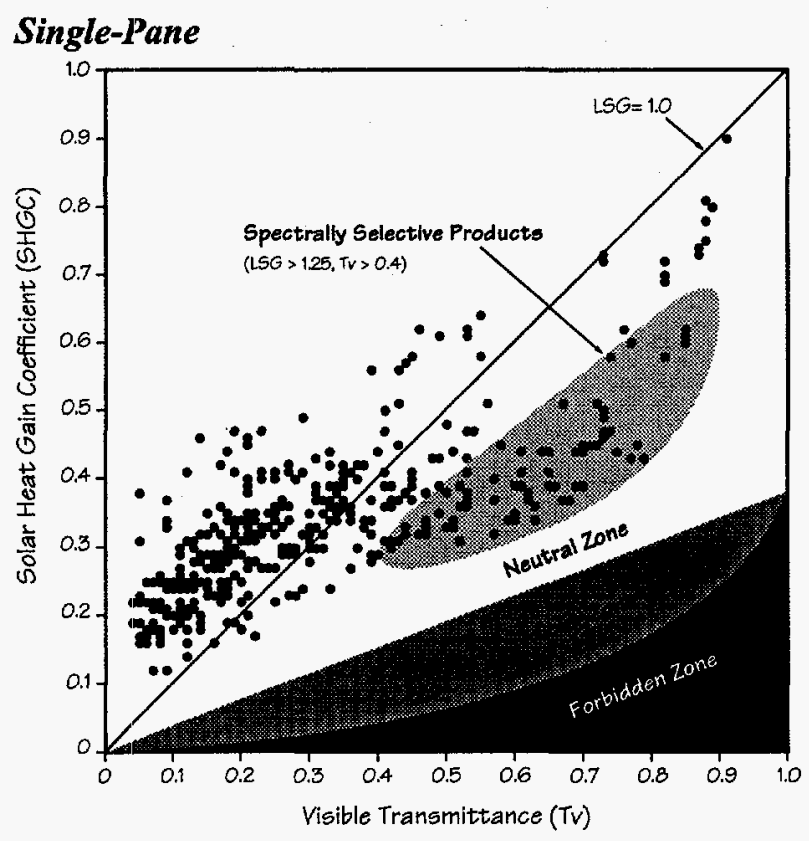

Triple-Fine

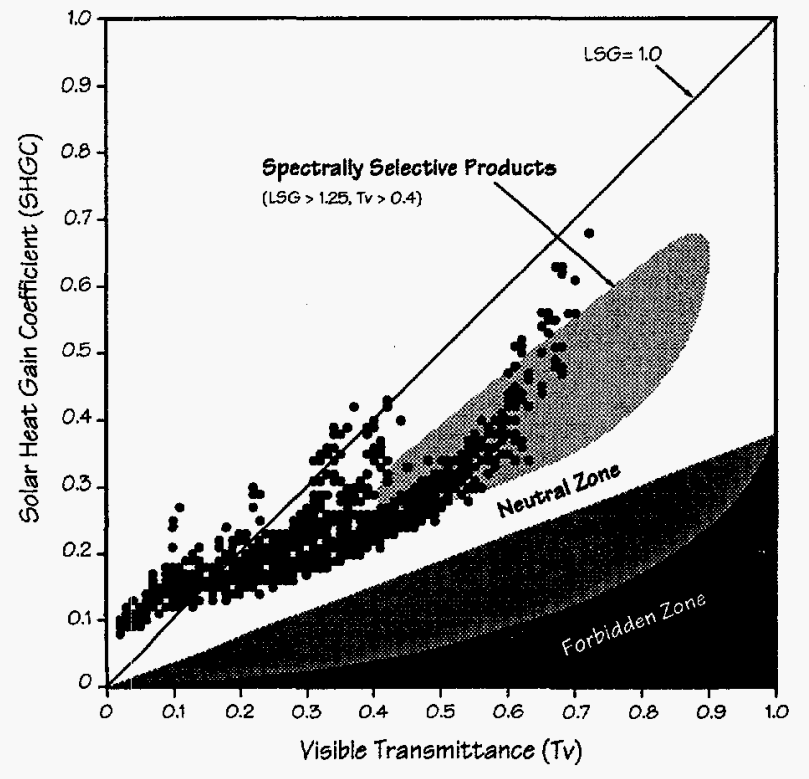

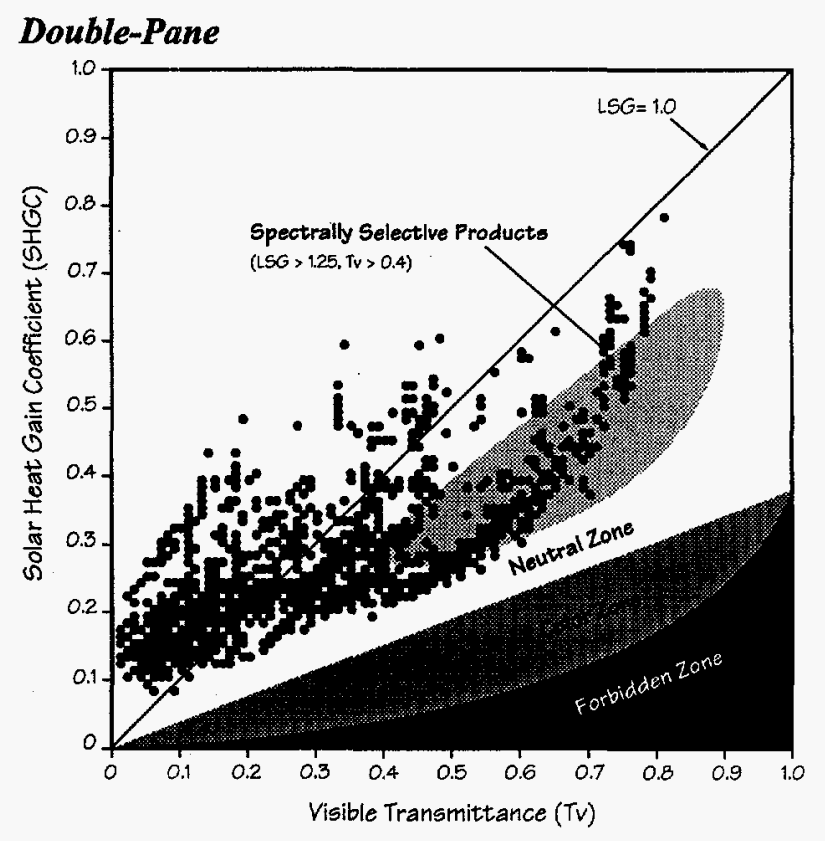

Properties of commercially available, spectrally selective glazings for nonresidential applications: single-pane, doublepane, and triple-pane products. 


\section{Residential Applications}

\section{Single-Pane}

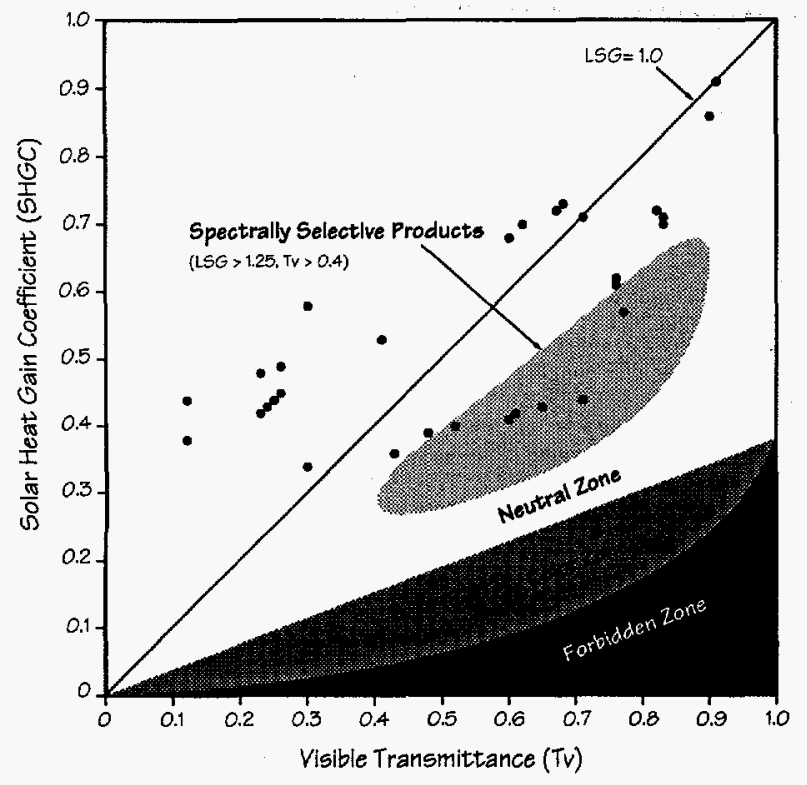

Triple-Pane

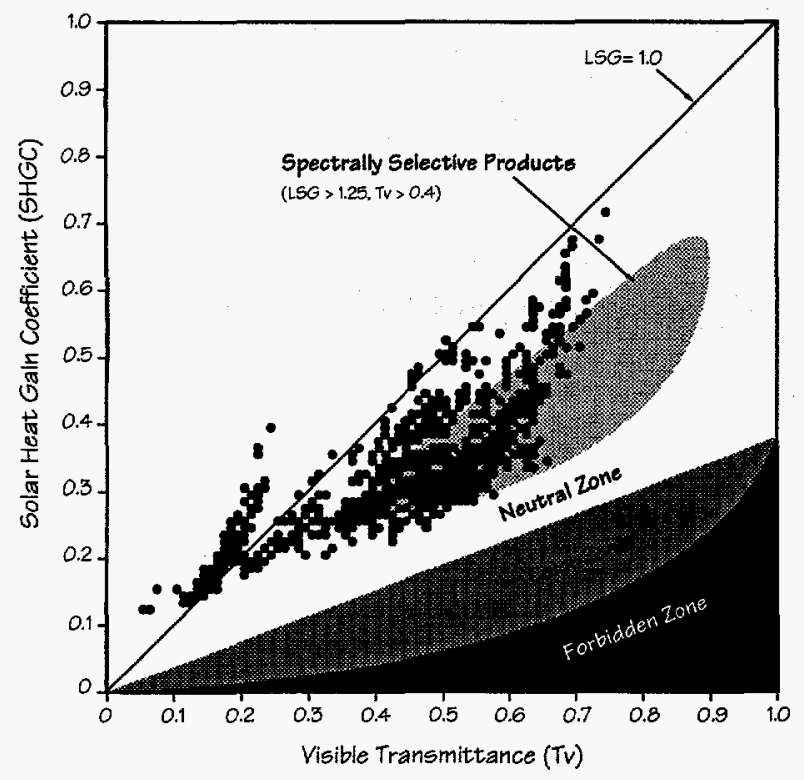

\section{Double-Pane}

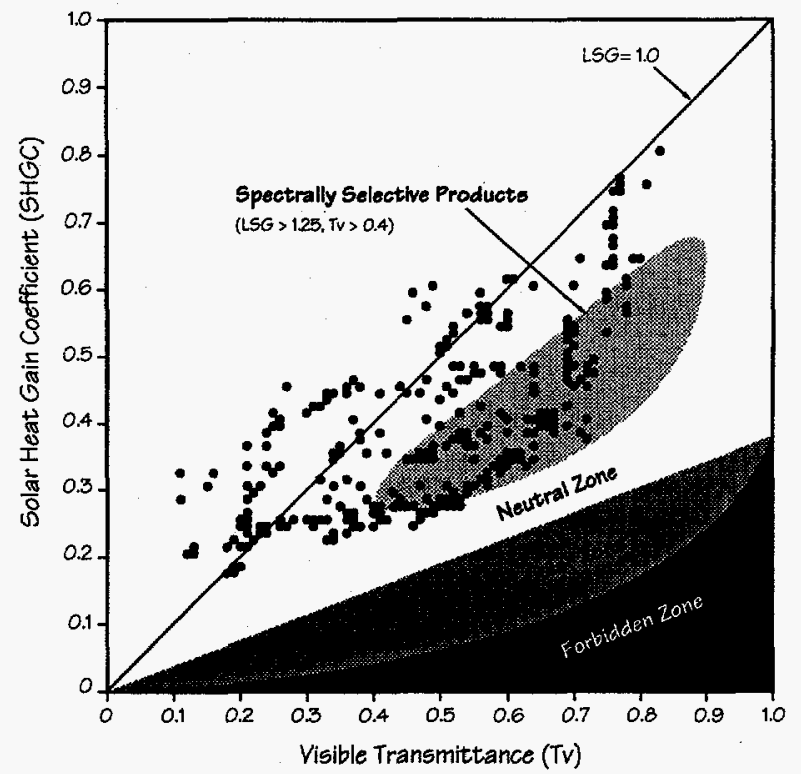

Properties of commercially available, spectrally selective glazings for residential applications: single-pane, doublepane, and triple-pane products. 


\section{Appendix B}

\section{Energy Performance Analysis}

Energy performance of commercial glazing systems for this FTA was modeled and evaluated using the DOE-2.1E Building Energy Simulation Program. The DOE-2 program is the building industry standard, requiring as input a geometrical description of the building and a physical description of its construction, HVAC equipment, end-use load schedules, utility rates, and hourly weather data to determine building energy consumption. A five-zone prototypical office building module, consisting of ten 3.05-m-(10- $\mathrm{ft})$ wide by $4.57-\mathrm{m}-(15-\mathrm{ft})$-deep offices in each perimeter zone and a central $929-\mathrm{m}^{2}\left(10,000-\mathrm{f}^{2}\right)$ core zone was modeled in five climates. Perimeter zones were oriented to face the four cardinal directions. Continuous strip windows were modeled in the exterior wall of each perimeter zone. Glazing area was varied from $0 \%$ to $70 \%$ window-to-wall ratio (WWR) where the wall area was defined as the floor-to-floor exterior wall area, and the floor-to-floor height was $3.66 \mathrm{~m}(12 \mathrm{ft})$.

The performance of the glazing systems was determined assuming the use of an interior diffusing shade. The shade is modeled as "manually operated," drawn down completely by the occupant during daylight hours if direct sun or glare is present. The shade was triggered if the transmitted direct solar radiation exceeded $94.5 \mathrm{~W} / \mathrm{m}^{2}\left(30 \mathrm{Btu} / \mathrm{h} \cdot \mathrm{ft}^{2}\right)$ or if the glare index computed using the Hopkinson Cornell-BRS formula exceeded 20. With the shade drawn, the Tv of the glazing was reduced by $35 \%$ and the SHGC by $25 \%$. Although the components are "conventional," they are not yet in routine commercial use; the assumed operation is optimistic for a manually controlled shade.

The electric lighting system was designed to provide 538 lux $(50 \mathrm{fc})$ of workplane illuminance at a lighting power density of 16.15 $\mathrm{W} / \mathrm{m}^{2}\left(1.5 \mathrm{~W} / \mathrm{ft}^{2}\right)$ and incorporated, when noted, a continuous dimming control system. The lighting was dimmed to a minimum light output of $10 \%$ with a minimum power output of $33 \%$ if the daylight workplane illuminance level at the task location was equal to or greater than $538 \mathrm{lux}(50 \mathrm{fc})$. Forty percent of the electric lighting system heat gains were vented to the return air plenum.

To isolate the energy effects relevant to glazing, interior surfaces were modeled as adiabatic (i.e., no heat transfer occurs). The effect of the thermal capacitance of the building was not studied. The building was modeled with lightweight construction. The exterior walls were modeled as no-mass quick walls with U-factor $=0.52 \mathrm{~W} / \mathrm{m}^{2} \cdot \mathrm{K}\left(0.091 \mathrm{Btu} / \mathrm{h} \cdot \mathrm{ft}^{2} \cdot{ }^{\circ} \mathrm{F}\right)$. The floors were modeled as adiabatic surfaces consisting of carpeting with a fibrous pad [U-factor $\left.=2.73 \mathrm{~W} / \mathrm{m}^{2} \cdot \mathrm{K}\left(0.481 \mathrm{Btu} / \mathrm{h} \cdot \mathrm{ft}^{2}{ }^{\circ} \mathrm{F}\right)\right]$ over a $0.10-\mathrm{m}-(0.33-\mathrm{ft}-)$ thick, $5-\mathrm{kg} / \mathrm{m}^{3}$ $\left(80-\mathrm{lb} / \mathrm{ft}^{3}\right)$ concrete slab. The ceiling was modeled as an adiabatic surface consisting of $0.013-\mathrm{m}(0.0417-\mathrm{ft})$ acoustical tile with the concrete floor slab above it. The interior partitions consisted of $0.016-\mathrm{m}(0.0521-\mathrm{ft})$ gypsum board over stud walls.

To isolate zone loads from building system interactions, a separate single-zone constant-volume system was assigned to each zone. A constant cooling system coefficient of performance $(\mathrm{COP}=3.0)$ converted the system loads to energy use. Hourly data therefore reflects a fixed COP for part-load performance and variations in exterior temperature and humidity conditions. Proportional thermostat cooling setpoints for weekdays were $22.2^{\circ} \mathrm{C}\left(72^{\circ} \mathrm{F}\right)$ between $7: 00$ and $19: 00$ and $32.2^{\circ} \mathrm{C}\left(90^{\circ} \mathrm{F}\right)$ between 19:00 and 7:00, and $32.2^{\circ} \mathrm{C}$ for all hours of weekends and holidays. The design cooling temperature was set at $25.6^{\circ} \mathrm{C}\left(78^{\circ} \mathrm{F}\right)$.

For each climate, a simple payback was calculated based on electricity and gas energy savings at a cost of $\$ 0.064 / \mathrm{kWh}$ and $\$ 0.36 /$ therm, respectively. The payback was based on the incremental glazing materials cost from the defined baseline glazing to the spectrally selective coating on clear glazing and the spectrally selective coating on selective tinted glazing. Peak demand reductions were also determined (W/ $\mathrm{ft}^{2}$ of floor area) compared to the spectrally selective coating on clear glazing. All window orientations were assumed to have the same glazing area. 


\section{Appendix C}

\section{Energy, Peak Demand, and Cost Data from the Simulations}

In Tables 1 and 2 (on the following pages) we give annual electricity consumption, peak electrical demand, and annual heating consumption data for a prototypical commercial office building module, determined using the DOE-2 simulation program. These data can be used to determine roughly the viability of spectrally selective glazings for a particular building application. For commercial buildings, an hour-by-hour building energy simulation program—such as DOE-2 (see "For Further Information"), which uses hourly weather data and can model the thermodynamics of advanced window systems - will provide more accurate estimates for a specific building. We delineate the steps to select and evaluate spectrally selective glazing options in Appendix D.

Glazing area is varied from $15 \%$ to $60 \%$ of the exterior floor-to-floor wall area. We also present performance data with and without the use of daylighting controls, which automatically dim electric lights if sufficient daylight is available in the room. Data are given for the climates of Madison, WI; Los Angeles, CA; Miami, FL; and Phoenix, AZ. 
Table 1. DOE-2 Energy Performance Data for No Daylighting Controls Case

\begin{tabular}{|c|c|c|c|c|c|c|c|c|c|c|c|c|c|c|}
\hline \multirow{2}{*}{$\begin{array}{l}\text { Glass } \\
\text { Area }\end{array}$} & \multirow[t]{2}{*}{ Glasing } & \multirow[t]{2}{*}{ Type } & \multicolumn{4}{|c|}{$\begin{array}{l}\text { Annual Electricity Consumption } \\
\text { (WWhitr'-glass) }\end{array}$} & \multicolumn{4}{|c|}{$\begin{array}{l}\text { Peak demand } \\
(\text { Whit'-noor) }\end{array}$} & \multicolumn{4}{|c|}{$\begin{array}{l}\text { Amnual Theatiog Consumption } \\
\text { (kWhitéglass) }\end{array}$} \\
\hline & & & Madison & I. & Miami: & Phoenix & Marison & IAA & Mrami: & Phoenix & Madison & EA & Mirami: & Phoenix \\
\hline \multirow[t]{6}{*}{0.15} & Single Clear & 1 & 77.58 & 81.79 & 101.23 & 102.47 & 4.99 & 5.06 & 5.22 & 5.66 & 96.47 & 1.70 & 0.24 & 2.13 \\
\hline & Double Bronze & 2 & 72.30 & 75.41 & 92.84 & 91.05 & 4.50 & 4.44 & 4.74 & 4.97 & 68.74 & 1.02 & 0.15 & 1.15 \\
\hline & Double Reflective & 3 & 70.61 & 72.46 & 88.48 & 84.34 & 4.21 & 4.16 & 4.46 & 4.63 & 70.87 & 1.45 & 0.20 & 1.50 \\
\hline & Double Low-E & 4 & 71.64 & 74.87 & 91.65 & 87.97 & 4.43 & 4.31 & 4.67 & 4.77 & 57.17 & 0.67 & 0.09 & 0.71 \\
\hline & Double Selective Clear & 5 & 71.16 & 74.18 & 90.40 & 86.23 & 4.36 & 4.25 & 4.59 & 4.69 & 57.18 & 0.73 & 0.10 & 0.76 \\
\hline & Double Selective Tint & 6 & 71.78 & 75.34 & 92.19 & 88.55 & 4.43 & 4.35 & 4.69 & 4.80 & 54.59 & 0.56 & 0.07 & 0.61 \\
\hline \multirow[t]{6}{*}{0.30} & Single Clear & 1 & 47.91 & 49.13 & 62.24 & 65.55 & 6.40 & 6.53 & 6.57 & 7.39 & 72.77 & 1.87 & 0.26 & 2.45 \\
\hline & Double Bronze & 2 & 40.68 & 42.58 & 53.08 & 54.14 & 5.27 & 5.35 & 5.55 & 6.03 & 46.33 & 0.89 & 0.12 & 1.17 \\
\hline & Double Reflective & 3 & 36.29 & 37.03 & 45.60 & 46.10 & 4.51 & 4.54 & 4.74 & 5.19 & 51.13 & 1.50 & 0.19 & 1.65 \\
\hline & Double Low-E & 4 & 38.57 & 40.80 & 50.41 & 50.40 & 4.98 & 4.96 & 5.20 & 5.52 & 34.68 & 0.44 & 0.06 & 0.56 \\
\hline & Double Selective Clear & 5 & 37.22 & 39.26 & 48.89 & 47.87 & 4.80 & 4.73 & 5.08 & 5.26 & 35.14 & 0.50 & 0.07 & 0.61 \\
\hline & Double Selective Tint & 6 & 38.82 & 41.77 & 51.28 & 51.11 & 5.00 & 5.08 & 5.25 & 5.60 & 32.02 & 0.32 & 0.05 & 0.43 \\
\hline \multirow[t]{6}{*}{0.45} & Single Clear & 1 & 37.95 & 38.50 & 49.26 & 52.89 & 7.74 & 8.05 & 8.00 & 9.04 & 64.26 & 1.92 & 0.29 & 2.57 \\
\hline & Double Bronze & 2 & 30.73 & 31.73 & 40.05 & 41.92 & 6.15 & 6.24 & 6.35 & 7.08 & 38.18 & 0.94 & 0.13 & 1.23 \\
\hline & Double Reflective & 3 & 26.12 & 26.06 & 32.43 & 33.84 & 4.98 & 5.03 & 5.24 & 5.86 & 43.28 & 1.61 & 0.20 & 1.78 \\
\hline & Double Low-E & 4 & 28.37 & 30.02 & 37.46 & 38.32 & 5.65 & 5.67 & 5.88 & 6.37 & 26.72 & 0.40 & 0.06 & 0.54 \\
\hline & Double Selective Clear & 5 & 27.04 & 28.44 & 35.86 & 35.64 & 5.38 & 5.33 & 5.73 & 5.94 & 27.02 & 0.44 & 0.06 & 0.59 \\
\hline & Double Selective Tint & 6 & 28.63 & 31.00 & 38.36 & 38.97 & 5.72 & 5.84 & 5.95 & 6.44 & 24.04 & 0.28 & 0.04 & 0.39 \\
\hline \multirow[t]{6}{*}{0.60} & Single Clear & 1 & 32.82 & 33.03 & 42.37 & 46.31 & 8.98 & 9.52 & 9.33 & 10.62 & 59.40 & 1.92 & 0.31 & 2.59 \\
\hline & Double Bronze & 2 & 25.80 & 26.33 & 33.62 & 35.71 & 6.99 & 7.09 & 7.19 & 8.12 & 33.90 & 0.98 & 0.13 & 1.28 \\
\hline & Double Reflective & 3 & 21.23 & 20.61 & 25.82 & 27.77 & 5.48 & 5.52 & 5.72 & 6.53 & 39.04 & 1.69 & 0.21 & 1.85 \\
\hline & Double Low-E & 4 & 23.29 & 24.59 & 30.91 & 32.19 & 6.34 & 6.35 & 6.51 & 7.18 & 22.70 & 0.40 & 0.06 & 0.54 \\
\hline & Double Selective Clear & 5 & 21.98 & 23.03 & 29.31 & 29.57 & 5.96 & 5.93 & 6.33 & 6.63 & 22.96 & 0.43 & 0.06 & 0.59 \\
\hline & Double Selective Tint & 6 & 23.60 & 25.61 & 31.85 & 32.87 & 6.41 & 6.57 & 6.61 & 7.28 & 19.98 & 0.26 & 0.04 & 0.3 \\
\hline
\end{tabular}


Table 2. DOE-2 Energy Performance Data for Daylighting Controls Case

\begin{tabular}{|c|c|c|c|c|c|c|c|c|c|c|c|c|c|c|}
\hline \multirow{3}{*}{$\begin{array}{l}\text { Glass: } \\
\text { Area: }\end{array}$} & \multirow{3}{*}{ Glaking. } & \multirow{3}{*}{ Mrue } & \multirow{2}{*}{\multicolumn{4}{|c|}{$\begin{array}{l}\text { Ammual Electricity Consumption } \\
\text { (aWWhr'-glass) }\end{array}$}} & \multirow{2}{*}{\multicolumn{4}{|c|}{$\begin{array}{l}\text { Pealk demand } \\
\text { (Whit' Boon) }\end{array}$}} & \multirow{2}{*}{\multicolumn{4}{|c|}{$\begin{array}{l}\text { Amual Heating Consumption } \\
\text { (LWWIt't2.glass) }\end{array}$}} \\
\hline & & & & & & & & & & & & & & \\
\hline & & & Marifison: & 18 & Mrami & Phoenix & Mardison & 1.8 & Mani & Phoeni: & Madison & I.A. & Marm & Phoenix \\
\hline \multirow[t]{6}{*}{0.15} & Single Clear & 1 & 60.63 & 60.34 & 77.37 & 80.18 & 4.67 & 4.73 & 4.87 & 5.37 & 105.64 & 2.03 & 0.27 & 2.43 \\
\hline & Double Bronze & 2 & 62.16 & 61.71 & 77.21 & 75.60 & 4.28 & 4.21 & 4.52 & 4.74 & 72.47 & 1.15 & 0.16 & 1.29 \\
\hline & Double Reflective & 3 & 67.26 & 67.80 & 83.52 & 79.01 & 4.13 & 4.08 & 4.36 & 4.57 & 72.35 & 1.51 & 0.21 & 1.56 \\
\hline & Double Low-E & 4 & 61.90 & 61.80 & 76.62 & 73.85 & 4.20 & 4.07 & 4.42 & 4.62 & 60.25 & 0.76 & 0.10 & 0.79 \\
\hline & Double Selective Clear & 5 & 62.00 & 61.84 & 76.34 & 72.81 & 4.13 & 4.02 & 4.34 & 4.53 & 60.20 & 0.83 & 0.11 & 0.85 \\
\hline & Double Selective Tint & 6 & 58.31 & 57.81 & 72.09 & 70.02 & 4.16 & 4.09 & 4.40 & 4.63 & 58.98 & 0.67 & 0.09 & 0.71 \\
\hline \multirow[t]{6}{*}{0.30} & Single Clear & 1 & 37.80 & 37.27 & 49.14 & 52.90 & 6.12 & 6.20 & 6.20 & 7.05 & 79.94 & 2.18 & 0.30 & 2.76 \\
\hline & Double Bronze & 2 & 32.29 & 31.90 & 41.09 & 42.93 & 4.99 & 5.03 & 5.20 & 5.73 & 50.66 & 1.07 & 0.14 & 1.35 \\
\hline & Double Reflective & 3 & 32.95 & 32.46 & 40.63 & 40.32 & 4.31 & 4.29 & 4.55 & 4.89 & 53.15 & 1.63 & 0.20 & 1.81 \\
\hline & Double Low-E & 4 & 30.35 & 30.31 & 38.47 & 39.47 & 4.66 & 4.64 & 4.83 & 5.26 & 38.19 & 0.55 & 0.08 & 0.67 \\
\hline & Double Selective Clear & 5 & 29.37 & 29.13 & 37.25 & 37.33 & 4.45 & 4.42 & 4.70 & 4.99 & 38.71 & 0.62 & 0.08 & 0.73 \\
\hline & Double Selective Tint & 6 & 29.13 & 29.96 & 38.47 & 38.81 & 4.67 & 4.73 & 4.89 & 5.32 & 36.41 & 0.43 & 0.06 & 0.54 \\
\hline \multirow[t]{6}{*}{0.45} & Single Clear & 1 & 30.86 & 30.33 & 40.28 & 44.22 & 7.45 & 7.75 & 7.62 & 8.72 & 69.87 & 2.18 & 0.33 & 2.84 \\
\hline & Double Bronze & 2 & 24.33 & 23.90 & 31.17 & 33.60 & 5.87 & 5.90 & 5.93 & 6.74 & 42.03 & 1.09 & 0.15 & 1.41 \\
\hline & Double Reflective & 3 & 22.16 & 21.44 & 27.23 & 28.08 & 4.54 & 4.60 & 4.82 & 5.29 & 46.69 & 1.81 & 0.22 & 2.01 \\
\hline & Double Low-E & 4 & 22.04 & 22.19 & 28.51 & 30.00 & 5.37 & 5.32 & 5.42 & 6.03 & 29.78 & 0.49 & 0.07 & 0.66 \\
\hline & Double Selective Clear & 5 & 20.83 & 20.62 & 26.68 & 27.47 & 5.01 & 4.99 & 5.16 & 5.62 & 30.25 & 0.56 & 0.07 & 0.72 \\
\hline & Double Selective Tint & 6 & 21.80 & 22.87 & 29.28 & 30.45 & 5.42 & 5.48 & 5.54 & 6.11 & 27.30 & 0.36 & 0.05 & 0.49 \\
\hline \multirow[t]{6}{*}{0.60} & Single Clear & 1 & 27.38 & 26.85 & 35.53 & 39.80 & 8.70 & 9.21 & 8.91 & 10.30 & 63.90 & 2.14 & 0.34 & 2.82 \\
\hline & Double Bronze & 2 & 20.73 & 20.30 & 26.69 & 29.34 & 6.70 & 6.76 & 6.76 & 7.81 & 37.20 & 1.13 & 0.15 & 1.43 \\
\hline & Double Reflective & 3 & 17.46 & 16.41 & 20.89 & 22.63 & 4.94 & 5.03 & 5.18 & 5.87 & 42.56 & 1.91 & 0.24 & 2.10 \\
\hline & Double Low-E & 4 & 18.25 & 18.52 & 23.88 & 25.72 & 6.06 & 6.00 & 6.00 & 6.83 & 25.30 & 0.48 & 0.07 & 0.65 \\
\hline & Double Selective Clear & 5 & 16.92 & 16.89 & 21.98 & 23.12 & 5.58 & 5.57 & 5.70 & 6.26 & 25.82 & 0.54 & 0.07 & 0.71 \\
\hline & Double Selective Tint & 6 & 18.32 & 19.39 & 24.91 & 26.32 & 6.14 & 6.22 & 6.21 & 6.94 & 22.58 & 0.33 & 0.05 & 0.47 \\
\hline
\end{tabular}




\section{Appendix D \\ Federal Life-Cycle Cost Analysis for the Tucson Federal Building, Tucson, Arizona}

A life-cycle cost analysis was conducted for the Tucson Federal Building using annual energy consumption data generated by the DOE-2 building energy simulation program. Analysis was done for each building orientation with a flat utility rate of $\$ 0.066 / \mathrm{kWh}$ and $\$ 0.36$ / therm (no demand charge). Materials and installation cost for the glazing per facade per floor was $\$ 15 / \mathrm{ft}^{2}$-glass * $540 \mathrm{ft}^{2} / \mathrm{facade}=\$ 8100$.

\section{Input File:}

QBLCC filename $=$ TUCFED.QI

Analysis type $=$ Federal Analysis-Energy Conservation Projects

Project name $=$ Tucson Federal Building

Base Date of Study $=1998$

Service Date $=1998$

Study Period $=25$ years

Discount rate $=4.1 \%$

Inflation rate $=0.00 \%$

Cap replacements and residual values (if any) included as investment costs.

Residual values automatically calculated for capital components.

Residual values automatically calculated for capital replacements.

$\begin{array}{lccc}\text { Common energy data } & \# 1 & \# 2 & \# 3 \\ \text { Energy type: } & \text { Electric } & \text { Nat.Gas } & \\ \text { Units: } & (\mathrm{kWh}) & \text { (therm) } \\ \text { Price per unit: } & \$ 0.066 & \$ 0.360 \\ \text { Escalation type code: } & 2 & 2\end{array}$

Data for DOE escalation rates:

DOE Escalation Rate File $=$ ENCOST98

Rate Schedule Type $=2$

State Abbreviation $=\mathrm{AZ}$

DOE Price escalation rates for Electric

\begin{tabular}{|c|c|c|c|c|c|c|c|c|}
\hline Year & Rate(\%) & Year & Rate $(\%)$ & $\underline{\text { Year }}$ & Rate $(\%)$ & Year & $\underline{\text { Rate }(\%) \quad \text { Year }}$ & Rate $(\%)$ \\
\hline 1998 & -1.4486 & 2008 & -0.3254 & 2018 & -0.4098 & & & \\
\hline 1999 & -2.7501 & 2009 & 0.2176 & 2019 & 0.0588 & & & \\
\hline 2000 & -2.0965 & 2010 & -1.5201 & 2020 & 0.0588 & & & \\
\hline 2001 & -1.3446 & 2011 & -1.0474 & 2021 & 0.0000 & & & \\
\hline 2002 & -0.6057 & 2012 & -0.5571 & 2022 & 0.0000 & & & \\
\hline 2003 & -1.4220 & 2013 & -0.7283 & 2023 & 0.0000 & & & \\
\hline 2004 & -1.5971 & 2014 & -1.2415 & & & & & \\
\hline 2005 & -1.5183 & 2015 & -1.2571 & & & & & \\
\hline 2006 & -0.7974 & 2016 & -0.5208 & & & & & \\
\hline 2007 & -1.1790 & 2017 & -0.6399 & & & & & \\
\hline
\end{tabular}

DOE Price escalation rates for Nat. Gas

$\begin{array}{llllllllll}\text { Year } & \text { Rate }(\%) & \text { Year } & \text { Rate(\%) } & \text { Year } & \text { Rate(\%) } & \text { Year } & \text { Rate(\%) } & \text { Year } & \text { Rate(\%) } \\ 1998 & -0.8264 & 2008 & -0.2146 & 2018 & 0.2237 & & & \\ 1999 & -0.4167 & 2009 & -0.4301 & 2019 & 0.8929 & & \\ 2000 & -0.4184 & 2010 & -0.2160 & 2020 & 1.9912 & & \\ 2001 & -1.0504 & 2011 & -0.8658 & 2021 & 1.9523 & \\ 2002 & 0.0000 & 2012 & -0.6550 & 2022 & 1.7021 & \\ 2003 & -1.0616 & 2013 & -0.6593 & 2023 & 1.6736 & \\ 2004 & -0.6438 & 2014 & -0.6637 & & & \\ 2005 & -0.2160 & 2015 & -0.6681 & & & \\ 2006 & 0.2165 & 2016 & 0.4484 & & & & \\ 2007 & 0.6479 & 2017 & -0.2232 & & & \end{array}$


Number of alternatives in file $=8$

Number of groups in file $=4$

\begin{tabular}{|c|c|c|c|c|c|c|c|c|c|}
\hline \multirow{2}{*}{$\begin{array}{c}\text { ALT } \\
\#\end{array}$} & \multirow{2}{*}{$\begin{array}{l}\text { ALTERNATIVE } \\
\text { NAME }\end{array}$} & \multirow{2}{*}{$\begin{array}{l}\text { GROUP } \\
\text { CODE }\end{array}$} & \multirow{2}{*}{$\begin{array}{l}\text { LIFE } \\
(\mathrm{Y} / \mathrm{M})\end{array}$} & \multirow{2}{*}{$\begin{array}{l}\text { INITIAL } \\
\operatorname{COST}(\$)\end{array}$} & \multicolumn{2}{|c|}{$\begin{array}{l}\text { CAPITAL } \\
\text { REPLACEMENTS }\end{array}$} & \multirow{2}{*}{$\begin{array}{c}\text { ANNUAL } \\
\text { OM\&R } \\
\text { COST(\$) }\end{array}$} & \multicolumn{2}{|c|}{ NON-ANNUAL OM\&R } \\
\hline & & & & & FREQ* & $\operatorname{cosT}(\$)$ & & FREQ* & $\operatorname{cosT}(\$)$ \\
\hline 1 & north bronze & A & $30 / 0$ & 0 & $0 / 0$ & 0 & 0 & $0 / 0$ & 0 \\
\hline 2 & north select & A & $30 / 0$ & 8100 & $0 / 0$ & 0 & 0 & $0 / 0$ & 0 \\
\hline 3 & east bronze & B & $30 / 0$ & 0 & $0 / 0$ & 0 & 0 & $0 / 0$ & 0 \\
\hline 4 & east select & B & $30 / 0$ & 8100 & $0 / 0$ & 0 & 0 & $0 / 0$ & 0 \\
\hline 5 & south bronze & $\mathrm{C}$ & $30 / 0$ & 0 & $0 / 0$ & 0 & 0 & $0 / 0$ & 0 \\
\hline 6 & south select & $\mathrm{C}$ & $30 / 0$ & 8100 & $0 / 0$ & 0 & 0 & $0 / 0$ & 0 \\
\hline 7 & west bronze & $\mathrm{D}$ & $30 / 0$ & 0 & $0 / 0$ & 0 & 0 & $0 / 0$ & 0 \\
\hline 8 & west select & $\mathrm{D}$ & $30 / 0$ & 8100 & $0 / 0$ & 0 & 0 & $0 / 0$ & 0 \\
\hline
\end{tabular}

*FREQ $=$ Frequency of occurrence (in years/months)

\begin{tabular}{cccccc}
$\begin{array}{c}\text { ALT } \\
\#\end{array}$ & $\begin{array}{c}\text { ALTERNATIVE } \\
\text { NAME }\end{array}$ & $\begin{array}{c}\text { GROUP } \\
\text { CODE }\end{array}$ & $\begin{array}{c}\text { ANNUAL ENERGY USE } \\
\text { Electric } \\
(\mathrm{kWh}) \\
\# 1\end{array}$ & $\begin{array}{c}\text { Nat.Gas } \\
\text { (therm) } \\
\# 2\end{array}$ & $\begin{array}{c}\text { AN. ELEC. } \\
\text { DEMAND } \\
\text { CHARGE(\$) }\end{array}$ \\
\hline 1 & north bronze & A & 21096 & 1 & 0 \\
2 & north select & A & 15828 & 1 & 0 \\
3 & east bronze & B & 32609 & 0 & 0 \\
4 & east select & B & 21813 & 0 & 0 \\
5 & south bronze & C & 33022 & 0 & 0 \\
6 & south select & C & 22119 & 0 & 0 \\
7 & west bronze & D & 33804 & 0 & 0 \\
8 & west select & D & 22226 & 0 & 0
\end{tabular}

\section{Output File:}

\section{QuickBLCC (QBLCC 2.5-98) 03-21-1998/09:07:37}

QBLCC filename $=$ TUCFED.QI

Analysis type $=$ Federal Analysis--Energy Conservation Projects

Project name $=$ Tucson Federal Building

Base date of study $=1998$

Service date $=1998$

Study Period $=25$ years

Discount rate $=4.1 \%$

Annually recurring costs and energy costs discounted from end of year.

DOE energy price escalation rate file $=$ ENCOST98

Number of alternatives in file $=8$

Number of groups in file $=4$

Note: Project alternatives displayed in increasing order of investment cost

\begin{tabular}{lrrrr}
$\begin{array}{c}\text { Group code: A } \\
\begin{array}{c}\text { Alternative } \\
\text { Name }\end{array}\end{array}$ & $\begin{array}{c}\text { Investment } \\
\text { Costs* }\end{array}$ & $\begin{array}{c}\text { OM\&R } \\
\text { Costs }\end{array}$ & $\begin{array}{c}\text { Energy } \\
\text { Costs }\end{array}$ & $\begin{array}{c}\text { Total Life- } \\
\text { Cycle Costs }\end{array}$ \\
\hline north bronze & $\$ 0$ & $\$ 0$ & $\$ 18782$ & $\$ 18782<-$ MIN LCC \\
north select & $\$ 7606$ & $\$ 0$ & $\$ 14090$ & $\$ 21696$
\end{tabular}

Comparative measures are only calculated for the alternative with lowest LCC relative to alternative with the lowest present-value investment cost.

Can't compute comparative economic measures for an alternative against itself. 


\begin{tabular}{lrrrr}
$\begin{array}{c}\text { Group code: } B \\
\begin{array}{c}\text { Alternative } \\
\text { Name }\end{array}\end{array}$ & $\begin{array}{c}\text { Investment } \\
\text { Costs* }\end{array}$ & $\begin{array}{c}\text { OM\&R } \\
\text { Costs }\end{array}$ & $\begin{array}{c}\text { Energy } \\
\text { Costs }\end{array}$ & $\begin{array}{c}\text { Total Life- } \\
\text { Cycle Costs }\end{array}$ \\
\hline east bronze & $\$ 0$ & $\$ 0$ & $\$ 29025$ & $\$ 29025$ \\
east select & $\$ 7606$ & $\$ 0$ & $\$ 19415$ & $\$ 27021<-$ MIN LCC
\end{tabular}

Comparative measures are only calculated for the alternative with lowest LCC relative to alternative with the lowest present-value investment cost.

Comparative economic measures for east select relative to east bronze:

NET SAVINGS $=\$ 2004 ;$ SIR $=1.26 ;$ AIRR $=5.08 \%$

Ratio of present-value energy savings to total savings $=1.00$

\begin{tabular}{lcccc}
$\begin{array}{c}\text { Group code: } \mathrm{C} \\
\begin{array}{c}\text { Alternative } \\
\text { Name }\end{array}\end{array}$ & $\begin{array}{c}\text { Investment } \\
\text { Costs* }\end{array}$ & $\begin{array}{c}\text { OM\&R } \\
\text { Costs }\end{array}$ & $\begin{array}{c}\text { Energy } \\
\text { Costs }\end{array}$ & $\begin{array}{c}\text { Total Life- } \\
\text { Cycle Costs }\end{array}$ \\
\hline south bronze & $\$ 0$ & $\$ 0$ & $\$ 29390$ & $\$ 29390$ \\
south select & $\$ 7606$ & $\$ 0$ & $\$ 19686$ & $\$ 27292<-$ MIN LCC
\end{tabular}

Comparative measures are only calculated for the altemative with lowest LCC relative to alternative with the lowest present-value investment cost.

Comparative economic measures for south select relative to south bronze:

NET SAVINGS $=\$ 2098 ;$ SIR $=1.28 ;$ AIRR $=5.12 \%$

Ratio of present-value energy savings to total savings $=1.00$

\begin{tabular}{|c|c|c|c|c|}
\hline \multirow{2}{*}{$\begin{array}{l}\text { Group code: D } \\
\text { Alternative } \\
\text { Name }\end{array}$} & \multicolumn{4}{|c|}{ 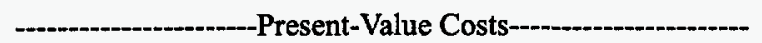 } \\
\hline & $\begin{array}{c}\text { Investment } \\
\text { Costs* }\end{array}$ & $\begin{array}{c}\text { OM\&R } \\
\text { Costs }\end{array}$ & $\begin{array}{l}\text { Energy } \\
\text { Costs }\end{array}$ & $\begin{array}{l}\text { Total Life- } \\
\text { Cycle Costs }\end{array}$ \\
\hline west bronze & $\$ 0$ & $\$ 0$ & $\$ 30088$ & $\$ 30088$ \\
\hline west select & $\$ 7606$ & $\$ 0$ & $\$ 19782$ & $\$ 27388$ \\
\hline
\end{tabular}

Comparative measures are only calculated for the alternative with lowest LCC relative to alternative with the lowest present-value investment cost.

Comparative economic measures for west select relative to west bronze:

NET SAVINGS $=\$ 2700 ;$ SIR $=1.35 ;$ AIRR $=5.37 \%$

Ratio of present-value energy savings to total savings $=1.00$

* Investment costs include capital replacements and residual values (if any). Residual values for initial capital investment are calculated when life extends beyond end of study period. Residual values for capital replacements are calculated when life extends beyond end of study period. 


\section{Appendix E}

\section{Federal Life-Cycle Costing Procedures and the BLCC Software}

Federal agencies are required to evaluate energy-related investments on the basis of minimum life-cycle costs (10 CFR Part 436). A life-cycle cost evaluation computes the total long-run costs of a number of potential actions, and selects the action that minimizes the long-run costs. When considering retrofits, sticking with the existing equipment is one potential action, often called the baseline condition. The life-cycle cost (LCC) of a potential investment is the present value of all of the costs associated with the investment over time.

The first step in calculating the LCC is the identification of the costs. Installed Cost includes cost of materials purchased and the labor required to install them (for example, the price of an energy-efficient lighting fixture, plus cost of labor to install it). Energy Cost includes annual expenditures on energy to operate equipment. (For example, a lighting fixture that draws 100 watts and operates 2,000 hours annually requires 200,000 watt-hours $(200 \mathrm{kWh})$ annually. At an electricity price of $\$ 0.10$ per $\mathrm{kWh}$, this fixture has an annual energy cost of \$20.) Nonfuel Operations and Maintenance includes annual expenditures on parts and activities required to operate equipment (for example, replacing burned out light bulbs). Replacement Costs include expenditures to replace equipment upon failure (for example, replacing an oil furnace when it is no longer usable).

Because LCC includes the cost of money, periodic and aperiodic maintenance (O\&M) and equipment replacement costs, energy escalation rates, and salvage value, it is usually expressed as a present value, which is evaluated by

$$
\mathrm{LCC}=\mathrm{PV}(\mathrm{IC})+\mathrm{PV}(\mathrm{EC})+\mathrm{PV}(\mathrm{OM})+\mathrm{PV}(\mathrm{REP})
$$

where $\quad P V(x)$ denotes "present value of cost stream $x$,"

IC is the installed cost,

$\mathrm{EC}$ is the annual energy cost,

$O M$ is the annual nonenergy $O \& M$ cost, and

REP is the future replacement cost.

Net present value (NPV) is the difference between the LCCs of two investment alternatives, e.g., the LCC of an energy-saving or energy-cost-reducing alternative and the LCC of the existing, or baseline, equipment. If the alternative's LCC is less than the baseline's LCC, the alternative is said to have a positive NPV, i.e., it is cost-effective. NPV is thus given by

or

$$
\left.\left.\left.\mathrm{NPV}=\mathrm{PV}\left(\mathrm{EC}_{0}\right)-\mathrm{PV}\left(\mathrm{EC}_{1}\right)\right)+\mathrm{PV}\left(\mathrm{OM}_{0}\right)-\mathrm{PV}\left(\mathrm{OM}_{1}\right)\right)+\mathrm{PV}\left(\mathrm{REP}_{0}\right)-\mathrm{PV}\left(\mathrm{REP}_{1}\right)\right)-\mathrm{PV}(\mathrm{IC})
$$

$$
\mathrm{NPV}=\mathrm{PV}(\mathrm{ECS})+\mathrm{PV}(\mathrm{OMS})+\mathrm{PV}(\mathrm{REPS})-\mathrm{PV}(\mathrm{IC})
$$

where subscript 0 denotes the existing or baseline condition,

subscript 1 denotes the energy cost saving measure,

IC is the installation cost of the alternative (note that the IC of the baseline is assumed zero),

ECS is the annual energy cost savings,

OMS is the annual nonenergy O\&M savings, and

REPS is the future replacement savings.

Levelized energy cost (LEC) is the break-even energy price (blended) at which a conservation, efficiency, renewable, or fuelswitching measure becomes cost-effective (NPV $>=0$ ). Thus, a project's LEC is given by

$$
\text { PV(LEC*EUS })=P V(\text { OMS })+P V(\text { REPS })-P V(I C)
$$

where EUS is the annual energy use savings (energy units/yr). Savings-to-investment ratio (SIR) is the total (PV) savings of a measure divided by its installation cost:

$$
\mathrm{SIR}=(\mathrm{PV}(\mathrm{ECS})+\mathrm{PV}(\mathrm{OMS})+\mathrm{PV}(\mathrm{REPS})) / \mathrm{PV}(\mathrm{IC})
$$

Some of the tedious effort of life-cycle cost calculations can be avoided by using the Building Life-Cycle Cost software, BLCC, developed by NIST. For copies of BLCC, call the FEMP Help Desk at (800) 363-3732. 


\section{About the Federal Technology Alerts}

The Energy Policy Act of 1992, and subsequent Executive Orders, mandate that energy consumption in the Federal sector be reduced by $30 \%$ from 1985 levels by the year 2005. To achieve this goal, the U.S. Department of Energy's Federal Energy Management Program (FEMP) is sponsoring a series of programs to reduce energy consumption at Federal installations nationwide. One of these programs, the New Technology Demonstration Program (NTDP), is tasked to accelerate the introduction of energy-efficient and renewable technologies into the Federal sector and to improve the rate of technology transfer.

As part of this effort FEMP is sponsoring a series of Federal Technology Alerts that provide summary information on candidate energy-saving technologies developed and manufactured in the United States. The technologies featured in the Technology Alerts have already entered the market and have some experience but are not in general use in the Federal sector. Based on their potential for energy, cost, and environmental benefits to the Federal sector, the technologies are considered to be leading candidates for immediate Federal application.
The goal of the Technology Alerts is to improve the rate of technology transfer of new energy-saving technologies within the Federal sector and to provide the right people in the field with accurate, up-to-date information on the new technologies so that they can make educated judgments on whether the technologies are suitable for their Federal sites.

Because the Technology Alerts are cost-effective and timely to produce (compared with awaiting the results of field demonstrations), they meet the short-term need of disseminating information to a target audience in a timeframe that allows the rapid deployment of the technologies - and ultimately the saving of energy in the Federal sector.

The information in the Technology Alerts typically includes a description of the candidate technology; the results of its screening tests; a description of its performance, applications and field experience to date; a list of potential suppliers; and important contact information. Attached appendixes provide supplemental information and example worksheets on the technology.
FEMP sponsors publication of the Federal Technology Alerts to facilitate information-sharing between manufacturers and government staff. While the technology featured promises significant Federal-sector savings, the Technology Alerts do not constitute FEMP's endorsement of a particular product, as FEMP has not independently verified performance data provided by manufacturers. Nor do the Federal Technology Alerts attempt to chart market activity vis-a-vis the technology featured. Readers should note the publication date on the back cover, and consider the Alert as an accurate picture of the technology and its performance at the time of publication. Product innovations and the entrance of new manufacturers or suppliers should be anticipated since the date of publication. FEMP encourages interested Federal energy and facility managers to contact the manufacturers and other Federal sites directly, and to use the worksheets in the Technology Alerts to aid in their purchasing decisions.

\section{T cderal Lnergy Management Program}

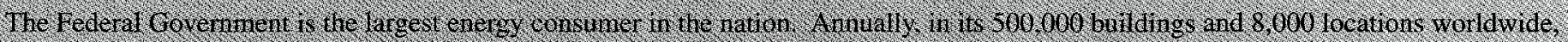

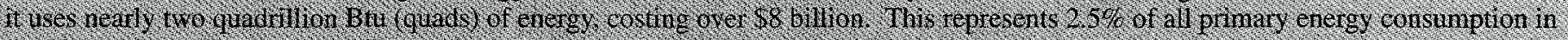

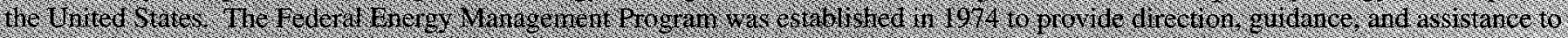

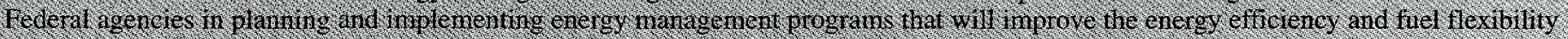
of the rederal infrastincture:

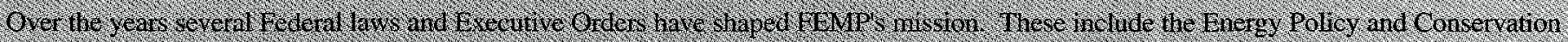

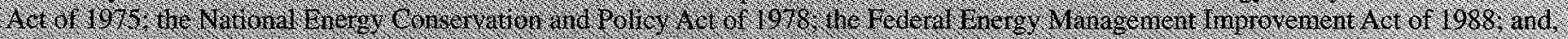

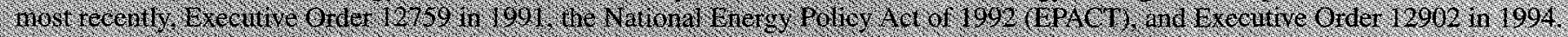

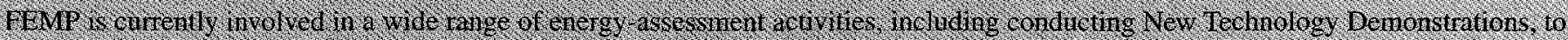
hasten lie penetration of enorgy eflictent technologies nto whe ledetal narketplace:

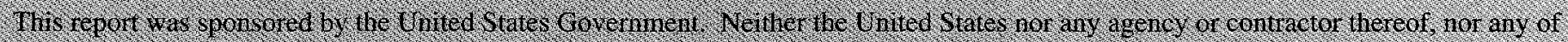

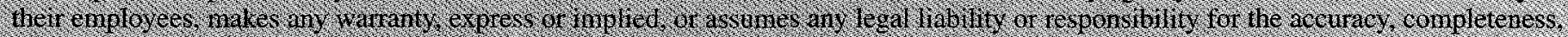

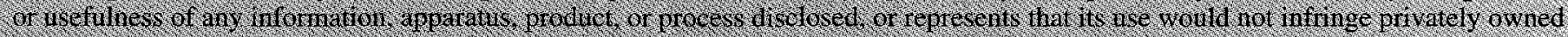

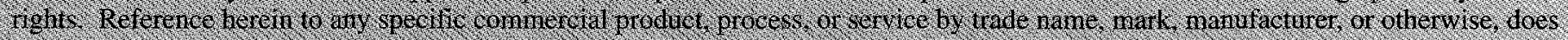

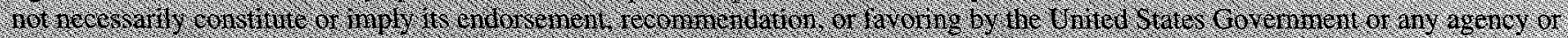

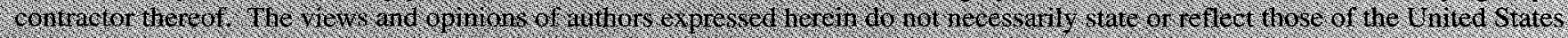

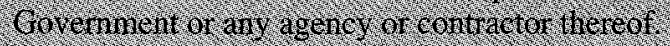


$8661.5 n 6 n$

SL10 asmad

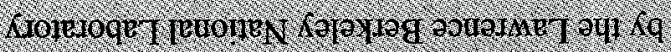

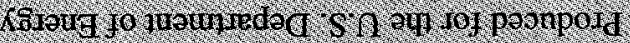

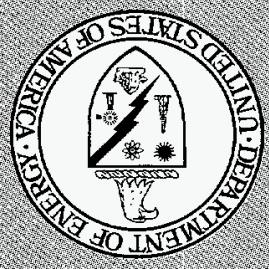

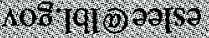
$6801-981(015) \times 101$ $166 t .981$ (01)

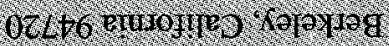

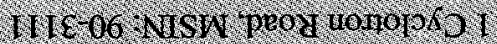

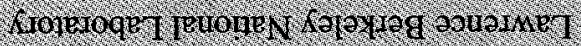
po) 010117

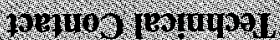

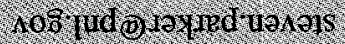

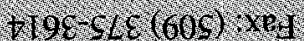
0989 \& L \& (60)

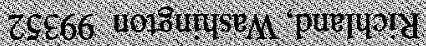

80 - 1 NISW 666 xag od

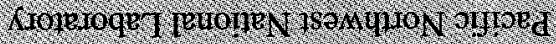
$10111 \mathrm{~d}, \mathrm{~V}, 12 \mathrm{r} / \mathrm{S}$

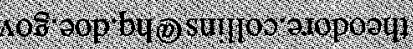

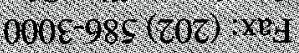
$1108.98 \mathrm{~s}(20)$

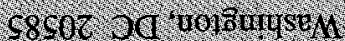

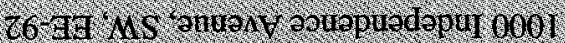

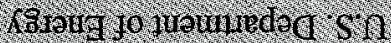

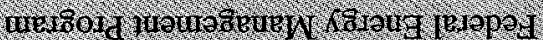
ranviv un Ror

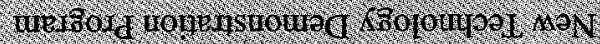
sum 100101

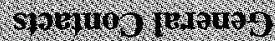

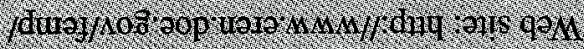

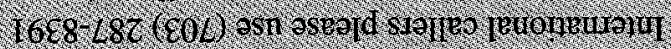
$0.6 \times 60,010)$

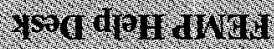

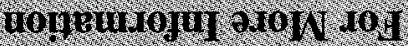

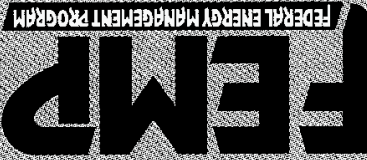

